\title{
Incumbent Effects and Partisan Alignment in Local Elections: a Regression Discontinuity Analysis Using Italian Data
}

\author{
Emanuele Bracco \\ Lancaster University
}

\author{
Ben Lockwood \\ University of Warwick \\ Michela Redoano* \\ University of Warwick
}

\author{
Francesco Porcelli \\ University of Exeter
}

First version: February 2011

This version: September 2014

\begin{abstract}
This paper provides a simple political agency model to explain the effect of political alignment between different tiers of government on intergovernmental grants and election outcomes. Key features of the model are (i) rational voters interpret public good provision as a signal of incumbent competence, and (ii) realistically, grants are unobservable to voters. In this setting, the national government will use the grant as an instrument to manipulate the public good signal for the benefit of aligned local incumbents. Then, aligned municipalities receive more grants, with this effect being stronger before elections, and the probability that the aligned local incumbent is re-elected is higher. These predictions are tested using a regression discontinuity design on a new data-set on Italian municipalities. At a second empirical stage, the national grant to municipalities is instrumented with an alignment indicator, allowing estimation of a flypaper effect for Italian municipalities.
\end{abstract}

KEYWORDS: Fiscal Federalism, Political Competition, Accountability.

JEL CLASSIFICATION: H2, H77, H87, D7

Address for correspondence; Department of Economics, Warwick University, Coventry, CV4 7 AL, United Kingdom. E-mail Michela.Redoano@warwick.ac.uk.

\footnotetext{
${ }^{*}$ We would like to thank Andreas Haufler, Carlo Perroni and seminar participants at Warwick, Lancaster and Catholic University in Milan, PET 2011, SIEP 2011, RES 2012, IIPF 2012 and SIE 2012 Conferences for helpful comments. Financial support from CAGE (Warwick) is gratefully acknowledged.
} 


\section{Introduction}

This paper focuses on the implications for local public finance, in particular, for intergovernmental grants, of three common features of fiscal decentralization. The first is that there is vertical imbalance i.e. degree of decentralization in expenditures is significantly higher than the degree of decentralization in tax revenue collection. For example, data from the World Bank Decentralization Database show that on average across over more than hundred countries and 29 years only over half of subnational expenditures are covered by subnational taxes. This vertical imbalance between fiscal capacity and fiscal needs is mostly covered by transfers from the central government. ${ }^{1}$ In some countries the allocation of these transfers is formulabased, while in others it is discretionary, giving central government potential scope for using grants for political goals.

A second common feature is that there are typically shared responsibilities between national and local governments in the provision of complex and important services such as health and education. For example, in the UK, the central government sets the school curriculum, and supervises exam marking, but local governments build and run schools, and hire teachers. Again in the education sector, in Italy the central government has sole responsibility for hiring teachers and deciding curricula, but school buildings are under the responsibility of provincial governments (for high schools) and municipal governments (for primary schools). At the same time regional governments are responsible for vocational training and bursaries. This second feature means that it is plausible that voters may have difficulty assigning credit (or blame) for the quality of these services between a number of different levels of government.

A third feature is that local government is typically party-political: that is, mayors and councillors have often party affiliations, and the same parties operate at both the national and local level, so that the national and local incumbent parties may be aligned or non-aligned.

This paper studies how these last two features interact to shape the design of discretionary grants, local public expenditure and taxation, and local incumbency advantage. We take a principal-agent approach to modeling the relationship between voters and politicians, as in Alesina and Tabellini (2007). The local public good is produced from fiscal resources (local tax revenue plus the grant) and also depends on local incumbent effort and ability. Both local and national incumbents are quasi-benevolent; local incumbents care both about re-election and voter welfare, whereas national incumbents care about voter welfare, and the election of aligned local politicians. We can show that in this setting, the national government will give larger grants to aligned incumbents. This result is not new; Arulampalam et. al. (2009) have the same finding in a distributive politics model where a national government can "buy" support from swing

\footnotetext{
${ }^{1}$ These figures are based on own calculations on data from the World Bank Decentralization Indicators, available at http://www1.worldbank.org/publicsector/decentralization/fiscalindicators.htm. In particular we compute averages over 108 countries and 29 years (1972-2000) of the ratios between subnational tax Revenues and grants as a proportion of total subnational fiscal capacity.
} 
voters for aligned local incumbents. What is new is that our result is established in a micro-founded political agency model, where the mechanism at work can be identified. Specifically, a higher grant raises local public good provision, and the latter signals a higher local incumbent ability to the electorate. This provides an incentive for the center to donate to districts with aligned incumbents. So, ours is a theory of intergovernmental grants as arising from the manipulation of signals by the center, rather than by the offering of bribes by the center, in contrast to the standard political economy theory of grants (Cox and McCubbins(1986), Dixit and Londregan(1995, 1998))

Second, we develop a number of empirical predictions of our theory. The first one, is of course, an alignment effect in grants. The second, which is new, is that a higher grant increases the probability of incumbent re-election, so that there is an alignment effect on incumbency advantage. Third, we predict that the alignment effect is stronger in election years than in non-election years. We also predict that conditional on grants, (i) local spending and taxes are independent of alignment, and (ii) there is a flypaper effect i.e. a one dollar increase in the grants has a bigger positive effect on local government spending than does an equivalent rise in private income. These last two predictions suggest that the flypaper effect can be identified by instrumenting grants by the alignment status of the local government.

We then take these predictions to an original data-set on Italian mayoral elections and public finance for the period 1998-2010. ${ }^{2}$ Italy constitutes a very good laboratory to test our hypotheses, as in Italy, grants from central government to municipalities have a large discretionary element, unlike most other OECD countries ${ }^{3}$. Our dataset includes almost 500 municipalities between 1998 and 2010, ruled by elected local governments, and around $25 \%$ of their current expenditure is funded by grants from the central and regional governments. There is no implicit or explicit formula for these grants, and each year a Budget Bill determines total grant for all municipalities, and the distribution of this total. Local taxes and fees cover most of the remaining $70 \%$ of local current expenditure. Local revenues are highly dependent on a property tax, ICI, which voters pay directly to their municipality. Moreover in the period covered by our data-set there have been three rounds of elections at the central level, while we observe local elections every year. The incumbent party at the central level has changed three times (in 2001, 2006 and 2008), and each year local elections were held in a number of municipalities. This gives us the variation in alignment that is needed to test our theory.

Our empirical strategy to identify the alignment effects on grants and incumbent advantage uses a regression discontinuity design. ${ }^{4}$ Specifically, we compare municipalities where the elected mayor is just

\footnotetext{
${ }^{2}$ Data of Italian mayoral elections are taken for the period 1998-2008, therefore for the last two years we included in the sample only municipalities that did not have elections.

${ }^{3}$ Formula grants are extensively adopted, for example, in: Australia (82\% at local level), Austria (98\%), Denmark (97\%), Portugal (85\%), France (95\%), United Kingdom. Discretionary ones are highly employed, for example, in Australia (at state level 90\%), Czech Republic (88\%), Turkey (100\%). Data are our calculations from OECD Revenue Statistics, 2005 edition.

${ }^{4}$ The advantage of this design is that it overcomes a fundamental identification problem-the potential correlation
} 
aligned with central governments with ones where the mayor is just unaligned, where "just aligned" means that the mayor won the election with a small margin and that the mayor and the central government belong to the same party. Using this design, we find highly significant alignment effects that are robust across a number of different specifications, for both grants and incumbency. If a municipality is politically aligned with the party in power at the central level, it will be rewarded with on average, $40 \%$ more grants than unaligned municipalities. The probability that the aligned incumbent mayor (or his coalition) is re-elected in the election is, on average, $30 \%$ higher than in non-aligned ones. Moreover, this alignment effect is stronger in the run-up to municipal elections than afterwards, in line with the theory.

The first empirical results tell us that alignment is potentially an appropriate instrument to use in testing the effect of the grant on local expenditure and tax revenues. So, we test the effect of alignment on local expenditure and tax revenues ${ }^{5}$, instrumenting the grant by an alignment dummy and also the margin of alignment. The over-identification tests are passed, indicating that the instruments are valid and thus that alignment has no effect on local expenditure, independently of the grant. The IV estimates indicate the presence of a flypaper effect. First, public spending increases by about 0.4 Euros per capita for each Euro increase in grants. On the other hand, a Euro increase in private income has a negligible effect on public spending. So, the overall flypaper effect is around 0.4 , in line with the results surveyed in $\operatorname{Inman}(2008)$.

The paper is organized as follows. The next section discusses the related literature. Section 3 introduces the theoretical framework, and Section 4 presents the main theoretical results. Section 5 presents some background information on Italy, data description and the econometric strategy. Section 6 discusses the main empirical results on transfers, and Section 7 is devoted to the flypaper effect. Section 8 tests the alignment effect on incumbency, and Section 9 concludes.

\section{$2 \quad$ Related Literature}

Our work speaks to at least four related literatures. First, on the theoretical side, our paper develops a new political economy theory of intergovernmental transfers based on a principal-agent model of multilevel government. This extends the existing literature in two ways. First, there is now a huge literature on political agency (summarized in for example, Persson and Tabellini (2000), Besley (2006)), which stresses the role of elections in screening and monitoring politicians. However, this literature focusses on one level of government, and has hardly considered intergovernmental grants. One exception is Brollo

between fiscal choices and the ideological characteristics of its voters - to identify the alignment effect on tax setting, grant allocation and public spending. A similar approach, in the context of grant allocation only, has been used in independent works by Brollo and Nannicini (2012) and Migueis (2013).

${ }^{5}$ In the Online Appendix we propose two alternative exercise, where the dependent variable is in turn (i) municipality expenditure net of (national and regional) grants, which corresponds to the sum of local taxes and fees, (ii) the total amount of public expenditures. The results for the estimation of the flypaper effect are very similar and around $40 \%$ 
et. al. (2013), which shows how higher grants from central governments can have negative effects on the behavior of lower-level governments in that the higher the transfer, the greater the rent taken by the lower-level incumbent, and when entry of incumbents is endogenized, the less good is incumbent quality. However, in that paper, grants are treated as exogenous ${ }^{6}$. Our theoretical contribution is to endogenize the grant in a setting very similar to Brollo et. al. (2013). So, this paper is the first, to our knowledge, to study intergovernmental grants in an agency framework.

Our approach is also in contrast to a "distributive politics" theory of intergovernmental grants due originally to Lindbeck and Weibull (1987), Dixit and Londregan (1995), and extended to a fiscal federalism setting more recently by Dixit and Londregan (1998) and Arulampalam et. al. (2009) ${ }^{7}$. This literature takes a Downsian view; parties can pre-commit to intergovernmental transfers prior to the election, and these transfers are observable by voters, both strong assumptions. In Dixit and Londregan (1998), national parties choose intergovernmental transfers to maximize their vote share in the national election, taking into account any redistribution of these funds amongst voter groups by state governments. They find that the transfer from the center to a given state will be higher, the greater the average "clout" of voting groups in that state, where "clout" depends on the relative number of "swing" voters in that group, and how cheap those votes are to buy (the weight that voters in the group put on consumption relative to ideology).

Arulampalam et.al. (2009) modify the Dixit-Londregan set-up to allow transfers from national government to impact directly on voters' incomes, and assume that national governments do not contest an election, but rather design grants to maximize the vote share of the aligned local candidates. Moreover, they assume that if the local and national incumbents are not aligned, the "goodwill" or utility increment generated by the grant is shared between the local incumbent and challenger (the latter being by definition, aligned with the national incumbent, as there are only two parties). Specifically, it is assumed that the local incumbent gets a share $\theta$ of the goodwill, and local challenger $1-\theta$. The qualitative predictions of the theory depend crucially whether this share is greater than one half. This $\theta$ is simply taken as exogenous in their theory, and indeed cannot be meaningfully endogenized in their model. One contribution of our theoretical model is that it effectively endogenizes $\theta$; see Section 4 below for more discussion.

On the empirical side, there are several related literatures. First, there is the literature on political alignment effects on intergovernmental grants. There are a number of papers that establish, for various countries, that political alignment with the center generates higher levels of discretionary grant to the

\footnotetext{
${ }^{6}$ Bordignon, Gamalerio and Turati (2013) extend Brollo et. al. (2013) to allow for two "quality" dimensions of politicians. Richer municipalities (with larger tax bases) are more likely to attract "productive" rather than "rent seeking" politicians. In their paper, rather than grants, the exogenous variation is from the 1999 reform in Italy that gave municipalities the power to set a surcharge on the income tax.

${ }^{7}$ See Johansson (2003) for an empirical test of the distributive politics theory.
} 
local government, for example, Levitt and Snyder (1995) and Larcinese, Rizzo and Testa (2006) for the US, Solé-Ollé and Sorribas-Navarro (2008) for Spain, Arulampalam et. al. (2009) for India, Case (2001) for Albania, Rodden and Wilkinson (2004) for India, Brollo and Nannicini (2012) for Brazil, Migueis (2013) for Portugal. In particular, our theoretical finding that alignment effects are stronger in election years is consistent with Brollo and Nannicini (2012), who estimate the alignment effect on per capita average infrastructure transfers from the federal government to municipalities in the last two years of the mayoral term and in the first two years of the mayoral term. They find that aligned municipalities significantly receive more grants than unaligned one only in the last two years of the term.

Second, there is a large literature on incumbency advantage. In particular, several recent papers use a regression discontinuity design in order to estimate the advantage of incumbency in elections, relying on the fact that when the electoral race is very tight, the identity of the winning party is likely to be determined by pure chance. The main contributions include Lee (2001, 2008), Lee, Moretti and Butler (2004) and Ferreira and Gyourko (2009). The common finding is that an incumbent policy maker enjoys a considerable advantage in winning elections. ${ }^{8}$ Our approach differs from the above because we are not attempting to estimate the incumbent effect as such, but we estimate the effect of alignment on incumbency, i.e. we estimate whether being just aligned with the central government increases an incumbent mayor's chance of being re-elected compared with a just unaligned mayor.

Third, our paper also relates to the large empirical literature on the flypaper effect (for surveys, see Hamilton (1983) and Inman (2008)). One of the main problems faced by this literature is that intergovernmental grants may be endogenous, and thus unbiased estimates of the flypaper effect require either (i) identification of truly exogenous changes in intergovernmental grants as in Dahlberg et al. (2008), or (ii) appropriate instruments for grants, as in Knight (2002). Our work is a contribution to the second strand of the literature; we are the first, to our knowledge, to use alignment as an instrument to estimate the flypaper effect.

Finally our paper is related to Bracco and Brugnoli (2012) and Cioffi, Messina and Tommasino (2012); they both analyze Italian local public finance data to investigate the effect of political competition on policies. Bracco and Brugnoli (2012) focus on the effect mayoral electoral system on grant allocation and finds that plurality elected mayors received less grants than colleagues elected under dual ballot system. Cioffi, Messina and Tommasino (2012) find evidence of a political cycle for local capital expenditures in those municipalities where the mayors are not politically aligned with the central government coalition.

\footnotetext{
${ }^{8}$ For example Ferreira and Gyourko (2009) find that, in the US, Democratic mayors who barely win an election have about a $66 \%$ chance of winning the next election.
} 


\section{A Theoretical Framework}

\subsection{The Environment}

In a country there are two tiers of government: a central government, and $i=1, . . n$ local jurisdictions, also referred to as municipalities. There are two parties $L$ and $R$, which operate both at the central and local level. Without loss of generality, we assume that party $L$ is ruling at the central level and in a subset $M_{A}$ of local authorities, while the complementary subset of municipalities $M_{N}$ is ruled by party $R$. The subscripts $A$ and $N$ indicate that left-wing localities are aligned with the central government, while right-wing ones are non-aligned.

In each of two periods $t=1,2$, the incumbent mayor in municipality $i$ produces a local public good via the following production function

$$
g_{i t}=F\left(r_{i t}\right) \exp \left(e_{i t}+a_{i t}\right), r_{i t}=\tau_{i t}+T_{i t}
$$

where $e_{i t}, a_{i t}$ are incumbent's effort and ability levels, $\tau_{i t}$ is local tax revenue (from a property or income tax) and $T_{i t}$ is a transfer from the central government. So, $r_{i t}$ is total fiscal resources of the municipality, and is also equal to public expenditure. Also, we assume that $F\left(r_{i t}\right)$ is non-negative, increasing in $r_{i t}$, and concave. Then, under these assumptions, $g_{i t}$ is non-negative.

Finally, the incumbent abilities $a_{i t}$ are determined as follows. First, the initial incumbent's ability, $a_{i 1}$ is drawn from a distribution with mean zero, where the distribution is common knowledge between voters and the incumbent. If the initial incumbent retains office, his ability is the same in the second period i.e. $a_{i 2}=a_{i 1}$. If he loses office, $a_{i 2}=a_{c, i}$, where $a_{i}^{c}$ is the challenger's ability, drawn from the same distribution as $a_{i 1}$.

The order of events is as follows. In period 1, each incumbent mayor chooses $e_{i 1}, \tau_{i 1}, i=1, \ldots, n$, and the national government chooses $T_{i 1}, i=1, \ldots, n$. Then, $g_{i 1}$ is determined via (1). Having observed $g_{i 1}, \tau_{i 1}$ but not $e_{i 1}, T_{i 1}$, the voters in region $i$ vote in municipal elections for the incumbent or the challenger. The winners take office in period 2 and choose $e_{i 2}, \tau_{i 2}, i=1, \ldots, n$. The national incumbent does not face an election and retains office, and chooses $T_{i 2}, i=1, \ldots, n$ in period 2 .

\subsection{Payoffs}

In each municipality $i$, there are a large number (a continuum of measure 1 ) of identical voters who have utility

$$
u\left(g_{i t}, c_{i t}\right)=\ln g_{i t}+c_{i t}
$$

where $c_{i t}$ is consumption of a private good. The private budget constraint of voter $j$ in municipality $i$ at time $t$ is $c_{i t}=m_{j}-d\left(\tau_{i t}\right)$ where $m_{j}$ is private income, and $d\left(\tau_{i t}\right)$ is the cost to the household of tax 
revenue $\tau_{i t .}$. We assume $d(0)=0, d^{\prime}, d^{\prime \prime}>0, d(\tau)>\tau, \tau>0$, so that $d$ captures the sum of loss of income and any of deadweight losses and compliance costs of taxation. This specification is standard in the public finance literature (e.g. Bolton and Roland (1997)).

Substituting the budget constraint into (2), and ignoring $m_{j}$, we get a voter payoff over government policy of $\ln g_{i t}-d\left(\tau_{i t}\right)$. Moreover, following Dixit and Londregan (1998), voter $v$ in municipality $i$ has an ideological preference for the incumbent, measured negatively by $X_{i}$. So, voter $v$ 's overall payoff is

$$
\ln g_{i t}-d\left(\tau_{i t}\right)-X_{i}
$$

We assume $X_{i}$ is distributed independently across voters and uniformly on $\left[-1 /\left(2 \zeta_{i}\right), 1 /\left(2 \zeta_{i}\right)\right]$, with $\zeta_{i}$ inversely measuring the dispersion of ideological preferences in municipality $i$. So, $\zeta_{i}$ measures the strength of swing voting i.e. the sensitivity of voting choices to performance in office in municipality $i$.

The incumbent municipal politician is quasi-benevolent, i.e. cares about voter utility from $g_{i t}, \tau_{i t}$, but also dislikes effort and values the probability of winning the election $p_{i t}$ :

$$
\lambda\left(\ln g_{i t}-d\left(\tau_{i t}\right)\right)-\psi\left(e_{i t}\right)+p_{i t} V_{i t}, \lambda>0
$$

Here, $\lambda$ is the weight on voter welfare, and $V_{i t}$ is the continuation value of office for the incumbent, calculated at the point when policy is chosen at time $t$. In period 2 , by definition, $p_{i 2} \equiv V_{i t} \equiv 0$; it can be shown (see the online Appendix) that $V_{i 1}=V$ for all municipalities, and $p_{i 1}$ is determined as described below. Here, $\psi($.$) is a twice differentiable, strictly increasing and strictly convex cost of effort. We assume,$ without loss of generality, that $V=1$, so the re-election incentive is measured solely by $p_{i 1}$. Overall, (4) is quite a standard objective for the politician (see for example Besley (2006)).

The incumbent national politician is similarly quasi-benevolent, and also (as in Arulampalam et al. (2009)) cares about the payoffs of incumbents in aligned jurisdictions, and challengers in non-aligned jurisdictions. So, his payoff is

$$
\sum_{i \in M_{A}} p_{i t}+\sum_{i \in M_{N}}\left(1-p_{i t}\right)+\sum_{i \in M} \lambda\left(\ln g_{i t}-d\left(\tau_{i t}\right)\right)-\sum_{i \in M} T_{i t}
$$

where the cost of providing $T_{i t}$ to a municipality $i$ is normalized to unity. For simplicity, we assume a discount factor of one for all agents.

\subsection{Discussion}

The basic structure of the model is very similar to that of Brollo et al.(2013). The main differences are twofold. First, the details of the public good production function and voter utility function are somewhat different, and second, more importantly, we endogenize the transfer $T_{i}$ from central government. Note 
that a crucial assumption is that $T_{i}$ is not observed by the voter at the time of voting; without this, grants could not be used to signal. We believe that the assumption that $T_{i}$ is not observed is very realistic; voters typically do not understand the complex rules governing formula grants, much less understand how discretionary grants are allocated. Finally, note that the assumption that the incumbent does not know his own ability at the beginning of his term of office is a widely made one in the literature on political principal-agent models (e.g. Persson and Tabellini(2000), Alesina and Tabellini(2007)); it keeps the analysis tractable while allowing the incumbent to signal his ability via higher public expenditure in equilibrium.

\section{Theoretical Results}

We solve the model backwards. In the second period, voter payoffs are increasing in incumbent ability. In fact, as shown in the online Appendix, incumbents of all abilities choose the same levels of tax and effort in the second period, so that the difference in second period voter payoffs over government policy between incumbents with abilities $a, a^{\prime}$ is just $a-a^{\prime}$. So, because incumbent ability is persistent, the voter in $i$ wishes to re-elect the incumbent only if the difference between his expected first-period ability $a_{i 1}^{e}$, and zero, the expected ability of the challenger, is higher than the voter's ideological preference for the challenger, measured by $X_{i}$. So, the voter will re-elect the incumbent if

$$
a_{i 1}^{e} \geq X_{i}
$$

From now on, we drop time subscripts, as all relevant variables are first-period. So, we see from (5) that the probability of the incumbent winning, $p_{i}$, is generally

$$
p_{i}=\operatorname{Pr}\left(X_{i} \leq a_{i}^{e}\right)=0.5+\zeta_{i} a_{i}^{e}
$$

How is $a_{i}^{e}$ determined? We can assume without loss of generality that the voter makes his inference about $a_{i}$ by observing his utility from public good provision, which is

$$
\ln g_{i}=f\left(\tau_{i}+T_{i}\right)+e_{i}+a_{i}, f=\ln F
$$

Note that by the assumptions on $F, f$ is strictly increasing and concave. ${ }^{9}$ Then, if the voter expects effort and the transfer to be at levels $e_{i}^{e}, T_{i}^{e}$, but observes $\ln g_{i}$, his inferred value of $a_{i}^{e}$ must satisfy

$$
\ln g_{i}=f\left(\tau_{i}+T_{i}^{e}\right)+e_{i}^{e}+a_{i}^{e}
$$

\footnotetext{
${ }^{9}$ This functional form implies that effort and tax revenue are independent in the sense that $\frac{\partial^{2} \ln g}{\partial \tau \partial e}=0$. If the two inputs $\tau, e$ are complements i.e. this cross-partial is strictly positive, Propositions 1,3 and 4 would still hold. Proposition 2 instead would not, as - conditional on grants - aligned mayor would exert less effort and levy lower taxes.
} 
Then, combining (7), (8), we get

$$
a_{i}^{e}=f\left(\tau_{i}+T_{i}\right)+e_{i}-f\left(\tau_{i}+T_{i}^{e}\right)-e_{i}^{e}+a_{i}
$$

That is, voter expectations are rational, up to any error in forecasting $T_{i}, e_{i}$.

The incumbent politician in $i$ perceives his probability of victory to be the expectation of $p_{i}$ with respect to $a_{i}$. Combining (6),(9), we see that this is

$$
p_{i}^{e}=0.5+\zeta_{i}\left(f\left(\tau_{i}+T_{i}\right)+e_{i}-f\left(\tau_{i}+T_{i}^{e}\right)-e_{i}^{e}\right)
$$

So, local government $i$ chooses $\tau_{i}, e_{i}$ to maximize

$$
\lambda\left(f\left(\tau_{i}+T_{i}\right)+e_{i}-d\left(\tau_{i}\right)\right)-\psi\left(e_{i}\right)+0.5+\zeta_{i} p_{i}^{e}
$$

taking $T_{i}, T_{i}^{e}, e_{i}^{e}$ as given. The first-order conditions with respect to $\tau_{i}, e_{i}$ are:

$$
\lambda+\zeta_{i}=\psi^{\prime}\left(e_{i}\right), \lambda f^{\prime}\left(\tau_{i}+T_{i}\right)+\zeta_{i}\left(f^{\prime}\left(\tau_{i}+T_{i}\right)-f^{\prime}\left(\tau_{i}+T_{i}^{e}\right)\right)=\lambda d^{\prime}\left(\tau_{i}\right)
$$

respectively. In equilibrium, expectations are rational, i.e. $T_{i}^{e}=T_{i}, e_{i}^{e}=e_{i}$. So, (10) reduces to

$$
\lambda+\zeta_{i}=\psi^{\prime}\left(e_{i}\right), f^{\prime}\left(\tau_{i}+T_{i}\right)=d^{\prime}\left(\tau_{i}\right)
$$

The national government chooses $T_{i}$ to maximize

$$
\sum_{i \in M_{A}} \zeta_{i} p_{i}^{e}-\sum_{i \in M_{N}} \zeta_{i} p_{i}^{e}+\sum_{i \in M} \lambda\left(f\left(\tau_{i}+T_{i}\right)+e_{i}-d\left(\tau_{i}\right)\right)-\sum_{i \in M} T_{i}
$$

taking $\tau_{i}, e_{i}, T_{i}^{e}, e_{i}^{e}$ as given. By the same argument, at equilibrium, the first-order conditions with respect to $T_{i}$ are

$$
\begin{aligned}
& \left(\lambda+\zeta_{i}\right) f^{\prime}\left(\tau_{i}+T_{i}\right)=1, i \in M_{A} \\
& \left(\lambda-\zeta_{i}\right) f^{\prime}\left(\tau_{i}+T_{i}\right)=1, i \in M_{N}
\end{aligned}
$$

Collectively, these first-order conditions characterize any Nash equilibrium to the game between the central government and the $n$ municipalities. From these first-order conditions, we can then establish the following results, all of which are proved in the Online Appendix.

Proposition 1. Alignment effects on grants. If $i$ is aligned, and $j$ is non-aligned, then $T_{i}>T_{j}$.

The intuition is as follows. First, national government has a baseline incentive to give transfers, because it cares about voter welfare. This is captured by the terms $\lambda f^{\prime}$ in (12)-(13). In addition, the national government perceives that by raising $T_{i}$, there will be an unanticipated (by the voter) increase in 
$g_{i}$, and the incumbent will get the credit for this, raising the re-election probability $p_{i}$. So, the national government will want to give more to aligned districts, and less to non-aligned ones. This is captured by the term $\zeta_{i} f^{\prime}$ in (12), and $-\zeta_{i} f^{\prime}$ in (13).

We can now compare our results to Arulampalam et. al. (2009). They assume that with alignment, the "goodwill" or utility increase for the voter generated by the grant is all captured by the local incumbent, but with non-alignment, it is shared between the local incumbent and challenger in exogenous shares $\theta$, $1-\theta$ respectively. Their Proposition 1, one of their main results, states that aligned incumbents get higher grants, independently of voter responsiveness $\zeta_{i}$ when the share of credit going to the challenger, $\theta<0.5$, because when this holds, a grant to a non-aligned municipality unambiguously benefits the incumbent. In our micro-founded approach, building on well-known political economy models, we see that the non-aligned incumbent gets all the credit i.e. $\theta=1$.

Finally, note that Proposition 1 is a result for election years. By contrast, in the second period of the model, there are no alignment effects i.e. transfers to aligned and non-aligned municipalities are the same. So, generally, our empirical prediction is that alignment effects will be stronger in election years. The absence of an alignment effect in non-election years is an artefact of the simplicity of the model and such an effect could easily be introduced in a number of ways e.g. by supposing that the national government cares more about voter welfare in the aligned municipalities.

The second result says that alignment effects on local taxes and spending only work through transfers.

Proposition 2. No conditional alignment effect on local taxes and spending. Conditional on transfers, local tax revenue $\tau$ and spending $r=\tau+T$ are independent of alignment.

The proof of this is obvious from (11). Writing the relevant conditions out in full, for any municipality $i$, we have:

$$
f^{\prime}\left(\tau_{i}+T_{i}\right)=d^{\prime}\left(\tau_{i}\right)
$$

So, $\tau_{i}$ is independent of $e_{i}$, which does depend directly on alignment. It then follows directly from (14) that tax revenue and expenditure only depend on alignment via transfers. We can now be more precise about how transfers affect local taxes and spending:

Proposition 3. Effect of Transfers on local taxes and expenditure. A given increase in transfers will reduce taxes by

$$
\frac{d \tau}{d T}=-\frac{f_{r r}}{f_{r r}-d^{\prime \prime}}>-1
$$

and thus increase expenditures by

$$
\frac{d r}{d T}=1-\frac{f_{r r}}{f_{r r}-d^{\prime \prime}}>0
$$

The intuition for this result is that as the transfer $T$ rises, the marginal deadweight loss of taxation falls, encouraging the municipality to raise more revenue overall, and thus $\tau$ does not fall one-for-one 
with $T$.

This result leads to a prediction about the flypaper effect in our model. The flypaper effect is usually understood to be the stylized fact that grants have a bigger positive effect on local government spending than does an equivalent rise in private income $(\operatorname{Inman}(2008))$. In our setting, households preferences are linear in income (see (2)), so there is no private income effect on government spending. However, we see from Proposition 3 that $\frac{d r}{d T}>0$, so our model predicts a flypaper effect of transfers. Moreover, these results suggest a way of identifying the flypaper effect via the use of alignment as an instrument, as discussed in Section 8 below.

Finally, we ask how the alignment effect described in Proposition 1 impacts upon the fortunes of the incumbent in an election. We have seen that higher transfers from the center lead to greater public good provision, and one might expect that might help the incumbent win the election. It turns out that if all voters are fully rational, that is not the case; rational voters "see through" the higher $g_{i t}$ because they rationally anticipate that aligned incumbents get higher transfers.

However, it seems implausible that all voters behave like that; after all, the retrospective voting literature demonstrates empirically that good performance is rewarded (see for example Fiorina (1978) and Wolfers (2002)). This can be formalized in our model by assuming that there is a fraction $1-\beta$ of the voters who are "naive retrospective" i.e. they are more likely to re-elect the incumbent if they see that $g_{i 1}$ was higher (or equivalently, they received a higher utility $\ln g_{i 1}-d\left(\tau_{i 1}\right)$ in $t=1$ ). This can be contrasted with the "sophisticated retrospective" behavior of the fully rational voters in our model, who are more likely to re-elect the incumbent if they believe that $a_{i}$ was higher. ${ }^{10}$ Assume in particular that naive retrospective voter $v$ votes for the incumbent if $\ln g_{i 1}-d\left(\tau_{i 1}\right) \geq X_{i}$, where $X_{i}$ is distributed uniformly on $\left[-1 /\left(2 \zeta_{i}\right), 1 /\left(2 \zeta_{i}\right)\right]$, as for the rational voters. It is then straightforward to show that:

Proposition 4. Alignment effect on re-election probabilities. Assume that municipality $i$ is aligned, and $j$ is not. If some fraction $\beta>0$ of voters are naive retrospective, and $\zeta_{i} \geq \zeta_{j}$, the incumbent is more likely to be re-elected in $i$ than in $j$.

The intuition is simply that when voters are weakly more responsive in the aligned jurisdiction $\left(\zeta_{i} \geq \zeta_{j}\right)$, alignment weakly increases effort and strictly increases expenditure on the public good, thus increasing the level of the public good itself, and this increases the attractiveness of the incumbent for the naive retrospective voters.

\footnotetext{
${ }^{10}$ A similar result might be obtained with a multi-period model with solely forward-looking voters. In such a model all voters would be more likely to vote for the aligned incumbent, as long as aligned jurisdictions kept on offering more public good for less tax. Nevertheless, the model would be substantially more complicated than the current one, as one would need to include further assumptions as to what extent voters are forward looking, how much "memory" the serially-correlated ability $a_{i t}$ has; it would also require the formalization of upper-tier elections.
} 


\section{Empirical Analysis}

\subsection{Background Information on Italy}

In this section we present some relevant background information on the Italian electoral system and local public finance.

\subsubsection{Tiers of governments, elections and parties}

Italy is a unitary parliamentary republic ruled by a central government with three sub-national levels: regions (regioni), provinces (province), and municipalities (comuni); the latter are the subject of our analysis. Comuni are ruled by a city council (consiglio comunale), and an executive committee (giunta), headed by an elected mayor (sindaco). Mayors are in charge of appointing the members of the executive committee (giunta), to which tasks are delegated, including powers on land management and environment (water, sewage, public hygiene), local transport, local police, culture and recreation, education (nursery schools, complementary education services such as transport and meal service). Mayors also have some discretionary powers on how much fiscal revenue to raise.

Following a political reform that took place in 1992, mayors are directly elected for five-year terms ${ }^{11}$ and are subject to a two-term limit. Mayors and city council are elected together, with different rules applying to municipalities below or above the 15,000-inhabitant threshold (from now on referred to as small and large municipalities), according to the latest available census data. Mayors of small municipalities are elected by first-past-the-post, while mayors of large municipalities are elected by runoff. This means that if no mayoral candidate obtains an absolute majority, voters vote again on just two candidates, the winner and the runner-up of the first round.

Generally speaking, in our sample period both at the local and at the national level, the political system was dominated by two large electoral cartels, the center-right and the center-left. At the national level, the center-right coalition ruled Italy from 2001 to 2006 and again from 2008 to 2011. The center-left coalition, going from Communist parties to left-leaning Christian Democrats, ruled instead from 1996 to 2001, and then again from 2006 until 2008.

However, the two-tier electoral system means that the electoral cartels are less influential in the smaller municipalities. Specifically, in smaller municipalities, because of the first-past-the post system, there is less incentive for small parties and independents to form coalitions to support a single candidate, whereas in the larger municipalities, there is a strong incentive to field a candidate who can win at the first round. Coalitions, when they form, are usually easy to classify as left or right, because they usually affiliate with a national party. This means that the party of both the winning mayor and the other contestants in the

\footnotetext{
${ }^{11}$ Four years if elected before year 2000.
} 
election is much easier to classify as "left" or "right" in large municipalities.

This is shown in Table 1, which shows the type of party (or coalition of parties) of the winning mayors in all municipal elections from 1998 to 2008, using official data published by the Interior Ministry. Parties were classified as left or right, using the classification in Table AA4 of the Online Appendix. However, some could not be classified, for example, the lista civica. Table 1 indicates that for large municipalities, only a small fraction of the winners, about $5 \%$, could not be classified as left or right. However, in the case of small municipalities, the reverse is true, and most of the winners, around $66 \%$, could not be classified. Our study of alignment effects requires accurate identification of the party type (left or right). For this reason, we do not include the small municipalities in our data-set.

\section{Insert Table 1 about here}

\subsubsection{Local Public Finance}

Municipality expenditures are primarily in the areas of land management and environment (waste disposal, water, sewage, public hygiene), social services, education (schools, complementary education services), local transport, local police, culture and recreation. Municipalities' revenues come from two main sources: transfers from upper levels of government (mainly the central government) and own revenues (from own taxes and fees). ${ }^{12}$ The degree of fiscal autonomy for comuni (i.e. the percentage of own fiscal revenues as a percentage of total current revenues) increased sharply during the early Nineties, when a considerable part of intergovernmental grants was replaced by new local taxes, and it is now stable at around $30 \%$.

The main source of own revenue for Italian municipalities is a property tax, called ICI (Imposta Comunale sugli Immobili), ${ }^{13}$ introduced in 1992 and applied to real estate; the tax base is represented by the land registry income and mayors are free to set the tax rate within a given range $(0.4 \%$ and $0.7 \%$ of income). Other important source of own revenue are from the taxation of personal income, through the national income-tax surcharge, a waste disposal tax (TARSU), and fees (for example on the issue of parking permits and certificates, related to the occupation of public spaces and areas, on the use of public billboards).

Most of the remaining fiscal needs, about $30 \%$ of expenditure, are covered by intergovernmental grants (mainly unconditional) from the central government. It is important to note that these grants are not formula based. Every year, a Budget Bill determines the grant going to municipalities as a whole,

\footnotetext{
${ }^{12}$ The use of debt is strongly restricted by the so-called "Internal Stability and Growth Pact", through which the central government limits the possibility of local authorities to incur debts, in order to comply with the EU constraints on deficit and debt. Moreover, the Art.119 of the Italian Constitution states that local governments can use debt financing only to cover capital expenditures. Therefore, as our analysis is focused on current expenditures, we abstract from considering the debt as an active source of financing.

${ }^{13}$ The property tax changed name, after a reform, in 2012 becoming IMU (Imposta Municipale propria)
} 
and how it is distributed across municipalities. In practice, this involves a common percentage change (often negative in the last few years) for all municipalities, with an additional ad-hoc element, which is more likely to follow political, rather than efficiency and equity criteria. Indeed, the need for a radical reform of the whole grant allocation system towards a formula-based one has been widely recognized by Italian legislators ${ }^{14}$.

\subsection{Data Description}

Our data set comprises financial, census, and election data at the municipal level from 1998 to $2010^{15}$. As described above, we restrict the analysis to large comuni. This leaves us with a sample of 526 local councils and 4086 observations. ${ }^{16}$ Note also that, despite the fact the large municipalities only constitute about $10 \%$ in terms of number of comuni, over $60 \%$ of the population reside in large municipalities, which receive (depending on the year) between $64 \%$ and $71 \%$ of total central government transfers; detailed figures on grant allocation and population by municipality size are reported in Table AA5 of the Online Appendix.

Local elections take place in each municipality every five years, but not all at the same time. The large number of municipalities means that local elections occur every year in our sample (See Table 2 for detailed information). On the other hand, national elections have been held in 2001, 2006 and 2008, and at every national election, there has been a change in the ruling government coalition (from left to right in 2001 and from right to left in 2006, and again form left to right in 2008). Figure 1 visualizes the distribution of local governments by winning coalition for each year of the sample period. The figure is divided into four panels; the first and the third correspond to periods when the center-left coalition was in power at the national level, and second and the fourth correspond to the years dominated by a center-right national government.

\section{Insert Table 2 about here \\ Insert Figure 1 about here}

In our regression discontinuity design (RDD) setting our treatment is the political alignment with the central government. For this purpose we define the alignment variable, $A L$, equal to 1 if the mayor's party-coalition is the same as the coalition in power at the central level. Table 2 presents information on the number of elections by year and by winning coalition for aligned and non-aligned governments. It is interesting to note that the sample is equally split between aligned and non-aligned municipalities.

\footnotetext{
${ }^{14}$ For example the national law n.42/2009 establishes the need to put in place a mechanism for the aggregation of the necessary parameters to calculate standard expenditure needs. The aim of the reform, which is currently being implemented, is to replace the old discretionary regime with a formula-based one.

${ }^{15}$ The dataset comprises electoral data from 1998 to 2008 and fiscal data and controls from 1998 to 2010.

${ }^{16}$ This is the number of observations for which we observe no missing values for all variables of our dataset.
} 
Next, we construct our assignment variable for the RDD regressions, the margin of alignment, $M A$, as the difference between the percentage of votes obtained by the winning mayor and the percentage of votes obtained by the runner-up if the winner is aligned with the center, and minus this difference if the mayor is not aligned. So, the sign of the margin of alignment is constructed in a way such that mayors who are (not) aligned with the central government have a positive (negative) margin of victory. If the mayor is elected in the first round (because he or she got an absolute majority), the first-round results are used, if a second round is held, then second-round results are used instead, (Table AA6 in the Online Appendix reports detailed information on first and second round elections). These political indicators have been collected from the Statistical Office of the Italian Ministry of Internal Affairs.

Table 3 shows the distributions of observations between aligned and non aligned local governments and breaks down the figures by the margin of alignment. Overall we have 4759 observations, but, if we consider only elections close to treatment thresholds, namely with a value of $M A$ less than either $5 \%$ and $2 \%$, the number of observations reduces drastically to 536 and 221 respectively; however the proportion of aligned and non-aligned municipalities remains virtually unchanged. Tables AA7 and AA8 of the Online Appendix report disaggregated information on the number of elections held in each year by winning coalition and alignment status.

\section{Insert Table 3 about here}

Our main dependent variables are: (i) current transfers from the central government to municipalities and (ii) local tax revenue. We focus on current expenditures and transfers because they are more likely to track the yearly decisions of central governments at any point in time, unlike investment expenditures, which tend to be set for longer periods of time. All these variables are expressed in real per capita values and data are taken from the Italian Ministry of Internal Affairs. In particular, current transfers from the central government to municipalities are the item "trasferimenti correnti dallo Stato" in the municipality balance sheet.

Moreover we employ a set of other controls which are generally thought to affect local public finance outcomes. First, we include variables measuring socio-demographic and geographical characteristics of municipalities, comprising resident population, proportion of population less than 14 and over 65 years old (the source of these variables is the Italian Institute of National Statistics (ISTAT)). Second, we include economic variables, comprising income per capita from real estate and from other sources. The sources for these variables are the Ministry of Finance the Ministry of Interior.

Third, we include other political controls. First, we have dummies recording whether the incumbent mayor (or party) has been re-elected, if the mayor is elected at the second round, and if the municipality is aligned with the regional government. Moreover we also include dummies for political orientation both 
at the local and national level (the former equal to one if the mayor is supported by a center-left coalition and that latter equal to one if a center-left government is in power at the national level). Finally, we include an electoral cycle variable that records the number of years since the last local election. The sources for these variables are the Ministry of Interior.

Descriptive statistics for all the variables employed in the regressions are given in Table 4; figures refer to statistics for the full sample as well as for restricted samples, i.e. for local governments that are close to the treatment threshold, namely within a $M A$ of five and two percentage points.

\section{Insert Table 4 about here}

Looking at average per capita data for the full sample we can see that comuni's current public expenditures amount to 790 Euros per capita, $20 \%$ of which is funded by grants from the central government. Figures for the restricted versions of the data set $(M A<5 \%, M A<2 \%)$ are similar. Looking at our main controls, the values of the standard deviations suggest that there is a lot of variation within each variable included in the data set but not much difference between the three samples.

As a further description of the data, Table AA3 of the Online Appendix presents summary statistics for aligned and non-aligned local governments. We can observe that, municipalities aligned with the central government coalition significantly enjoy more grants from the central government (177.42 and 132.50 Euros per capita), and raise lower taxes (236.88 and 250.85). Finally, note that our samples are almost equally split between aligned and unaligned municipalities, which is the treatment variable we are interested in for the purposes of our analysis.

\section{Alignment and Transfers}

\subsection{Estimation Strategy}

In this section we test the prediction of Proposition 1 on the effect of alignment on grant allocation. We use regression discontinuity design (RDD) to address the identification problem in generating unbiased estimates of this alignment effect. The problem is that political alignment is determined by local characteristics that are unknown or unobservable by the researcher. To deal with this, we exploit the fact that alignment with the party ruling at the central government changes discontinuously at $50 \%$ of the vote share of local parties. This allows us to use sharp regression discontinuity design.

Following this approach, we compare municipalities where the elected mayor is barely aligned with central governments with those where the mayor is barely unaligned, where "barely aligned" means that the mayor won the election with a tight margin and that the mayor and the central government belong to the same party. Lee $(2001,2008)$ show that this approach represents quasi-random variation in party 
winners, because - as long as there are some unpredictability in voting behavior - when the race is very tight, the identity of the winning party is likely to be determined by pure chance.

There are various ways in which RDD can be implemented using both parametric and non parametric analyses; see Lee and Lemieux (2010) for an excellent survey. The simplest approach is to compare policy outcomes just around the treatment threshold; however this method can produce imprecise estimates and has to rely on a large sample size. Given the relatively limited number of observations available to us around the treatment threshold, our preferred strategy is to use an alternative approach which is based on the use of all available data together with a control function. This approach consists on regressing the dependent variable on a pth-order polynomial in the control function, in addition to the binary treatment indicator.

The model we estimate takes the following form:

$$
\ln T_{i, t}=\gamma_{0} A L_{i, t}+f\left(M A_{i, t} ; A L_{i, t}\right)+\beta^{\prime} X_{i, t}+\varsigma_{t}+\mu_{i}+v_{i, t}
$$

where $T_{i t}$, is the per capita grant to municipality $i$ at time $t$, and $A L_{i, t}$ is our alignment dummy that takes value of one if the ruling party at the local level in municipality $i$ is the same as the party in power at the central level; this is our treatment variable. Finally, $M A_{i, t}$, the margin of alignment, already defined above, is our assignment variable. Recall that all observations with a positive (negative) $M A_{i, t}$ are municipalities which are aligned (unaligned) with the central government, and observations with a small $M A_{i, t}$ in absolute value refer to mayors who won the elections with a very small margin. ${ }^{17}$

We allow $f\left(M A_{i, t} ; A L_{i, t}\right)$ to be a pth order polynomial in $M A_{i, t}$, with coefficients all interacted with $A L_{i t} .{ }^{18}$ Finally $X_{i t}$ is a vector of control variables, $\varsigma_{t}$ is a year dummy, and $\mu_{i}$ is the unobserved heterogeneity. We treat $\mu_{i}$ as a municipality fixed effect. The coefficient of interest is $\gamma_{0}$, which is our alignment effect at the zero threshold, and, following Proposition 1, its expected sign is positive.

As pointed out by Imbens and Lemieux (2008), the above estimation method may be sensitive to outcome values for observations far away from the threshold. To address this issue, as a robustness check, we also implement the local linear regression approach, which restricts the sample to municipalities in the interval $M A_{i, t} \in[-h,+h]$, where $h$ is an optimally chosen bandwidth, here selected following the methodology suggested by Imbens and Kalyanaraman (2009).

\footnotetext{
${ }^{17}$ It is important to emphasize that both the alignment dummy and the assignment variable refer to the previous year's observation. This is due to the fact that, in the sample, local and central elections have been held always between April and June, while the allocation of grants is decided by the central government by the end of December and the local fiscal policy is decided by local councils usually not later than March.

${ }^{18}$ That is, our control function is: $f=\beta_{01} M A_{i t}+\beta_{02} M A_{i t}^{2}+\ldots+\beta_{0 p} M A_{i t}^{p}+\beta_{1} A L_{i t} M A_{i t}+\beta_{2} A L_{i t} M A_{i t}^{2}+\ldots+$ $\beta_{p} A L_{i t} M A^{p}$.
} 


\subsection{The Effect of Alignment on Grants}

In this section we present the results on the alignment effect on grants. The results are displayed in Table 5. As the dependent variable is the log of the per capita grant, the coefficient $\gamma_{0}$ in equation (15) has the interpretation of the percentage change in per capita transfer due to the alignment effect. ${ }^{19}$ In all our specifications standard errors are clustered at municipal level.

The table is divided into three panels. In the first panel we display results for the so-called OLS regression model (which corresponds to equation (15) in the case of zero-order polynomial in the control function). In the second panel we report the estimated $\gamma_{0}$ in equation (15) considering the optimal polynomial order in the control function (according to tests reported in Table A1, the optimal polynomial order is the the 4th). The coefficients' point estimates obtained considering all polynomial orders are displayed in Table AA1 of the Online Appendix. We produce two sets of results, the first one generated by employing the full RDD sample, and the second one by restricting the sample to those municipalities whose mayor was elected in the second round. By doing so we address a possible concern on the robustness of our results due to the fact that $M A$ is calculated in the same way (i.e. as the percentage difference in the votes between the winner and the runner up) for elections where the mayor is elected in the first round and for those decided in a second round. ${ }^{20}$

Finally, in the bottom panel we report the results for the local linear regression model, where the sample is restricted to observations within an optimally chosen bandwidth, calculated following Imbens and Kalyanaraman (2009), using the full RDD sample. As a robustness checks we also present results for when the sample is restricted to double as well as half the optimal bandwidth size.

For each specification we propose three variations. In the first column, we run the regressions without additional controls, in the second one we include the full set of controls listed in Table 4 as well as year dummies, in the third column we also include a municipality fixed effect. As pointed out by PetterssonLindbom (2008), the inclusion of these additional covariates is a way of checking whether alignment status is as good as randomly assigned (conditional on $f\left(M A_{i t} ; A L_{i t}\right)$ ) and it should not significantly affect the estimate of the alignment effect. Finally, the last column reports the number of observations.

\section{Insert Table 5 about here}

\footnotetext{
${ }^{19}$ In a previous working paper version of this paper Bracco, Porcelli and Redoano (2013) we present results when the variables are in level, which are qualitatively similar.

${ }^{20}$ Recall that second-round elections are, by definition, elections with only two candidates, while in first round elections the number of candidates may vary. Second, the fact that a candidate obtains the majority of the votes in the first round can itself be interpreted as a sign of high popularity (or, in other words, low political competition in that municipality).This is clearly confirmed by looking at the summary statistics for the first round election dummy reported in Table 4. Taking the full sample, $44 \%$ of elections are decided in the second round, but if we look only at close races (i.e. MA less than $5 \%$ ), the proportion of second round elections goes up to $90 \%$.
} 
A common denominator to all these specifications is that the estimated effect of alignment on grants is always positive and generally highly significant. In order to obtain more precise estimates on the magnitude of the alignment effect in Table A1 we report the Akaike Information Criterion (AIC) as well p-values from the goodness-of-fit test (F-test), which provide formal guidance on the choice of the best polynomial order. ${ }^{21}$ According to these criteria the polynomial order that fits the data best is the fourth. Using the full sample, this means that a just aligned municipality should receive between $36 \%$ and $47 \%$ more grants than a just unaligned one. The specifications with and without controls produce very similar results and it is consistent with the hypothesis that the use of the control function makes redundant the inclusion of further controls. Also the magnitude of these coefficients is in line with the results obtained from the local linear regression model using an optimal bandwidth, which, in our case, restricts the sample to the observations within $\pm 13 \% M A$. The estimated coefficients for the local linear regression model are indeed between 0.33 and 0.44 . Moreover it is important to note that RDD coefficient estimates are more stable to the introduction of control variables than OLS coefficient estimates, showing that the control function reduces the risk of biased estimates due to the problem of omitted variables.

If we consider only municipalities where the mayor was elected in the second round the number of observations drops from 3141 to less than half (1263), but the results remain very similar to the ones previously analyzed. Note also that for this sub-sample, the margin of alignment is on average smaller, as can be clearly seen from Table 4. Full summary statistics for the sample of second round election are displayed in Table AA9 of the Online Appendix.

Finally, in Table A3 of the Appendix, we show that the effect of alignment on grants is stronger at the end of the term, as predicted by the theoretical model. In particular, in Table A3 we estimate the model (15) including, as an additional regressor, the interaction between the alignment dummy and the electoral cycle, defined in section 5.2, which records the number of years since the last election in the municipality. The coefficient of the interaction term is positive and statistically significant. In the same table we also provide a different specification of the electoral cycle defined by a dummy for the last year of the term. Again, the alignment effect is stronger at the end of the term. These last findings are in line with Brollo and Nannicini(2012).

\subsection{Graphical Analysis}

It is also interesting to look at the graphical representation of our RDD results displayed in Figures 2(a) and 2(b). Each figure shows the margin of alignment, $M A$, on the horizontal axis, and the per capita grant allocated to each municipality on the vertical axis. Figure 2(a) reports the fitted values from a

\footnotetext{
${ }^{21}$ Following Lee and Lemieux (2010), this is obtained by jointly testing the significance of a set of bin dummies included as additional regressors in the model. The bin width used to construct the bin dummies is 0.02 . A bin width of 0.01 has not been used because was generating to much collinearity in relation to the size of the sample.
} 
running-mean smoothing of per capita grants fitted over the interval $[-40,+40]$ in the $M A$, performed separately on each side of the cutoff point, as well as the $95 \%$ confidence intervals. Following Lee and Lemieux (2010) we include 50 bins in all figures. Figure 2(b) reports graphical representation of the local linear regression model of per capita grants in the $M A$ fitted over the optimal bandwidth.

\section{Insert Figure 2 about here}

The figures also help with the visualization of the estimated equation (15) to highlight not only the values of $\gamma_{0}$, the "jump" in the dark line at the zero threshold, but also the shape of the relationship between the outcome variable and the assignment variable. Figure 2(a) not also clearly shows the discontinuity in the distribution of grants between aligned and unaligned municipalities at $M A=0$ but also the fact the all aligned municipalities enjoy overall more grant than unaligned ones.

Further analysis in support of the correctness of the procedure we implement is provided in Figure A1 and Table A2. Using the McCrary (2008) procedure, Figure A1 shows a graph of the distribution of MA computed over bins with a bandwidth of 0.01 (100 bins in the graph), along with a smooth 4th-order polynomial model. ${ }^{22}$ The graph shows no evidence of discontinuity at the cutoff. Therefore, there is no statistical evidence of manipulation of the assignment variable around the cutoff. Another important test for the validity of the RD design is to examine whether the covariates do not exhibit any discontinuity in relation to $M A$. As suggested by Lee and Lemieux (2010) we test the null of discontinuities in all covariates simultaneously estimating a set of regressions where each covariate is a dependent variable, and the explanatory variables are $A L$, and the polynomial in $M A$. This system is estimated by Seemingly Unrelated Regression (SUR), and then we perform a chi-square test for joint hypothesis that $A L$ is insignificant in all regressions (zero discontinuity). As reported in Table A2 we cannot reject the null hypothesis of zero discontinuity in all covariates in relation to almost all polynomial orders of the margin of victory. Therefore, we can conclude that there is no statistical evidence of discontinuity in the covariates.

\section{The Turnover of Incumbents}

We now investigate our prediction that the probability of the incumbent mayor being re-elected is higher when aligned with the central government. To this, we estimate the following model:

$$
I_{i, e+1}=\gamma_{1} A L_{i, e}+f\left(M A_{i, e} ; A L_{i, e}\right)+\beta^{\prime} X_{i, e}+\tau_{e}+\mu_{i}+v_{i, e}
$$

Note that the temporal unit is now election years, $e$. The outcome variable is now $I_{i, e+1}$, which is equal to one if the winner of the local election at time $e+1$ is the same (or at least belongs to the same party)

\footnotetext{
${ }^{22}$ Higher order polynomial produce very similar results.
} 
as the winner in the previous election (held at time $e$ ) and zero otherwise. As before, $f\left(M A_{i, e} ; A L_{i, e}\right)$ is a polynomial function of up to fourth order in $M A_{i, e}$, where the coefficients are interacted with $A L_{i, e}$. The coefficient of interest is $\gamma_{1}$, which is our alignment effect on the probability of incumbent re-election; $\gamma_{1}$ should be interpreted as the difference between the (absolute) probability of re-election of the aligned incumbent and the unaligned one. We expect $\gamma_{1}$ to be positive.

The variable $I_{i, e+1}$ is calculated in two ways. First, we use a broad definition of incumbent, incumbent party, under which $I_{i, e+1}$ is equal to 1 if the winning mayor at elections held at time $e+1$ in municipality $i$ belongs to the same coalition as the winner of the elections at time $e$; this is quite consistent with the Italian case where usually the deputy mayor steps in when the incumbent mayor cannot re-run for elections. Second, we consider a narrower definition, incumbent candidate, where $I_{i, e+1}$ is equal to 1 only if the incumbent mayor is re-elected for the second time at $e+1$ and zero otherwise. So under this definition we exclude all the cases where the mayor cannot run because of term limits (there is a limit of two consecutive terms for Italian mayors).

\section{Insert Table 6 about here}

Table 6 reports results for different specifications of model (16), using the above two definitions of incumbent. Note that the number of observations is now drastically reduced since we are only using election years; for this reason, we display results only for the regressions where the full sample is employed. ${ }^{23}$ Note that in all specifications standard errors are clustered at municipal level. Using the AIC reported in Table A1 in the Appendix, the polynomial order that fits the data best is the second for both definitions of incumbent, so we will base our discussion on this polynomial order. The complete set of results related to other polynomial orders are reported in Table AA2 of the Online Appendix. Now our RDD sample comprises 363 observations if we use the incumbent party definition for $I_{i, e+1}$ and 205 for the incumbent candidate one. This relatively small number of observations explains why, when we estimate the model using a high polynomial order, the coefficients tend to lose significance. The estimated coefficients for the incumbent effect are between 0.20 and 0.31 (without and with controls) for the incumbent party and between 0.25 and 0.35 for the incumbent candidate, which means that being aligned with the central government at the time of election gives local incumbents a strong advantage in comparison to non-aligned ones. The inclusion of fixed and time effects and controls does not affect the magnitude or the significance of the coefficients.

\footnotetext{
${ }^{23}$ Regressions using only second round elections produce very similar results, but given the reduced number of observations (127) standard errors are larger than when the full sample is employed, and this obviously affects the significance of the coefficients. Output for 2 nd round elections is available upon request.
} 


\section{Insert Figure 3 about here}

The graphical visualization of our RDD estimations is displayed in Figures 3(a),(b) and it is clearly in line with the regression results. The figures show the plots of the probability of re-election within each bin against $M A$, the margin of alignment in the previous election. Following Lee and Lemieux (2010) we include 50 bins in all figures. We also report the fitted values from a running-mean smoothing of the variable on the vertical axis performed separately on each side of the cutoff point (the darker solid line) as well as the $95 \%$ confidence intervals (the two lighter lines). Both figures clearly show the "jump" in the probability of incumbent re-election around the zero threshold. Note also that while the probability of re-election for non-aligned mayors is strongly affected by their popularity (i.e. the margin of victory) in the previous elections, this is much less obvious for aligned candidates. At the right hand side of Figure 2(b), the fitted polynomial function is much flatter than the one displayed on the left hand side of the figure. This is consistent with the fact that marginal aligned mayors, facing potentially high probability of losing the election, receive extra help, i.e. more grants, from the central government.

\section{The Flypaper Effect}

The final step in our empirical analysis is to trace the effect of political alignment on taxes and expenditures via the grant. Following Knight (2002), we estimate:

$$
\tau_{i t}=\alpha T_{i t}+\beta^{\prime} X_{i t}+\varsigma_{t}+\mu_{i}+v_{i, t}
$$

where $\tau_{i t}$ is a measure of local tax revenue, to proxy for $\tau$ in the theoretical model. Also, $X_{i t}$ includes all the control variables employed in previous regressions and displayed in Table 4. Proposition 3 above suggests that $0>\alpha>-1$. Of course, $T_{i t}$ is endogenous, and our previous results suggest that we use the alignment dummy $A L_{i t}$, as an instrument, which we know to be correlated with $T_{i t}$.

Tables 7 reports the main results for model (17). In Table 7, the dependent variable is municipality core tax revenue, which comprises revenue from the (ICI) and the personal income tax, the two main source of municipal tax revenue. As a robustness check we also experiment with alternatives dependent variables (see Tables AA10 and AA11 in the Online Appendix): (i) municipality expenditures net of (national and regional) grants, i.e. revenues from taxes and fees and (ii) municipality expenditures. In all specifications, we report standard errors clustered at municipal level, which are robust for serial correlation and heteroscedasticity. We also include time dummies and the full set of controls. Due to space constraints, the coefficients on the controls are not reported, with the exception of the per capita private sector income (the variable "income per capita" in the tables), as this is needed for the calculation 
of the flypaper effect. ${ }^{24}$ Finally, municipality fixed effects are included in all specifications.

Let us discuss the results displayed in Table 7. The first column presents the results when equation (17) is estimated by OLS and $T_{i t}$ is treated as exogenous; in the following columns we present results for the 2SLS when $T_{i t}$ is instrumented with (i) the alignment dummy only; (ii) the alignment dummy as well as the fourth order polynomial function in $M A$; (iii) the alignment dummy, and the first order polynomial function in $M A$, and we restrict the sample to those observations falling within the optimal bandwidth employed in the local linear regression on grants above. For the 2SLS specifications, we include first and second stage regression outputs.

\section{Insert Table 7 about here}

When grants are not instrumented (column 1) our results suggest that an increase of 1 Euro per capita in grants reduces local taxes by 0.167 Euros, which means that there is an increase of overall public spending of about 0.83 Euros per capita. By contrast, conditional on the grant, a 1 Euro per capita increase in private income has no effect on public spending. The flypaper effect can be then measured as the difference between one plus the coefficient on the grant, and the coefficient on private income. So when grants are not instrumented, the flypaper effect in Italian municipalities is calculated to be around $83 \%$ percent $(1-0.169=0.83)$.

However the tests reported at the bottom of Table 7 indicate that the grants are endogenous (Hausman test) and that the alignment dummy is a good instrument for it (Sargan-Hansen test), so in the following column of the table we report results for IV estimation. When grants are instrumented (column 2 ) with the alignment dummy, the coefficient on grants becomes now -0.571 , and it is significant at $1 \%$. Private income per capita becomes significantly positive; however, the size of the effect is very small (a 1 Euro increase in private income gives at most a 1 cent increase in core tax revenue). Overall the extent of the flypaper effect decreases, going down to $0.43 \%$ (i.e. $1+(-0.571+0.006)$ ). This means that public spending increases of about 0.43 Euros per capita for each Euro increase in grants. This estimate is almost unchanged when we add a fourth-order polynomial in $M A$ as an additional instrument in column 3. The Sargan-Hansen test displayed at the bottom of the panel suggests that the excluded instruments are valid instruments. Moreover in both cases, an F-statistic on the significance of the first stage regressor is very large, suggesting that weak instruments are not a problem (Staiger and Stock (1997)). Finally, in the last column (column 4), we restrict the analysis to those municipalities whose margin of alignment in previous mayoral elections was within the optimal bandwidth (i.e. a value of $M A \pm 0.13 \%$ ). The sample shrinks from 3527 observations to 837 . The estimated coefficient on the grant is now -0.55 . So, overall,

\footnotetext{
${ }^{24}$ This variable is defined as total income declared in the tax return minus real estate income, since real estate income is used as a separate regressor to control for variation in the tax base of the property tax.
} 
the flypaper effect is estimated to be between $43 \%$ and $48 \%$. This estimate is in line with other studies in the survey by Inman (2008). In particular, Inman finds that across a large number of studies, the flypaper effect ranges from about 0.25 to 1.00 . It is worth noting that our finding (namely, that instrumenting decreases the flypaper effect) is similar to what is found in Knight (2002).

In order to test the validity of our results with respect to different measures of $\tau_{i t}$, we re-run model (17) using municipality expenditures net of (national and regional) grants (which is equivalent to revenues from taxes and fees) as the dependent variable. Table AA10, included in the Online Appendix, displays the results for this exercise. In Table AA11 we displayed the results for the estimation of model (17) using municipality expenditures as dependent variable. This specification has been usually employed in the past to investigate the extent of the flypaper effect. For both cases the results are consistent with those displayed in Table 7 .

\section{Conclusions}

This paper has explored both theoretically and empirically the effect of political alignment on local public finance and elections. Our model predicts that aligned jurisdictions are assigned more grants by the central government because a higher grant to aligned mayors (because not directly observed by voters) signals higher competence of that mayor and thus increases the probability of their re-election. Moreover, the model shows that part of the extra grants will be used to reduce taxes, and part to increase local expenditure, implying a flypaper effect.

We test these predictions using a new data set on Italian local public finance and elections over the 1998-2010 period. Our empirical strategy is based on regression discontinuity design (RDD), exploiting the fact that being or not aligned with the central government changes discontinuously at $50 \%$ of the votes at local election. Moreover, the RDD approach also provides a good identification strategy to estimate the relationship between grants and expenditure providing an unbiased measure of the flypaper effect.

Our empirical results are largely consistent with our theoretical predictions. In particular we find that, if a municipality is politically aligned with the party in power at the central level, it will be rewarded with an increase in grants between $36 \%$ and $47 \%$; moreover, the probability of re-election of aligned municipalities will be between $20 \%$ and $35 \%$ higher than for non-aligned local governments. Finally, we find a positive flypaper effect; $40 \%$ of each Euro of extra grants will be used to increase expenditure and $60 \%$ will be used, instead, to reduce local taxes.

The theoretical and the empirical analysis showed, in the end, that when local governments are responsible for the provision of local public goods, there is a perverse trade-off between the level of discretion in the distribution of intergovernmental grants and the disciplining and selection role of elections. In fact if grants are not formula-based and voters attribute, correctly, most of the credit for providing local public 
goods to the local government, then the central government will tend to divert resources toward aligned jurisdictions for electoral purposes, thus generating an inefficient allocation of resources. So, our analysis provides another reason why formula-based grants are to be preferred to discretionary ones.

\section{References}

Alesina, A., Tabellini, G. (2007). "Bureaucrats or Politicians? Part I: A Single Policy Task," American Economic Review, 97(1), 169-179.

Arulampalam, W., Dasgupta, S., Dhillon, A. and Dutta, B. (2009). "Electoral goals and center-state transfers: A theoretical model and empirical evidence from India," Journal of Development Economics, 88(1), 103-119.

Besley, T. (2006). Principled agents? The Political Economy of Good Government, Oxford Univ. Press. s

Bolton, P., Roland, G. (1997), "The breakup of nations: a political economy analysis", The Quarterly Journal of Economics, 112(4), 1057-1090.

Bordignon, M., Gamalerio, M., Turati, G. (2013). Decentralization, Vertical Fiscal Imbalance, and Political Selection, CESifo Working Paper No. 4459.

Bracco, E., Brugnoli, A., (2012). Runoff vs. Plurality. The Effects of the Electoral System on Local and Central Government Behavior, Working Paper. Department of Economics, Lancaster University Management School.

Bracco E., Porcelli, F., Redoano, M. (2013). Incumbent Effects and Partisan Alignment in Local Elections: A Regression Discontinuity Analysis Using Italian Data, CESifo Working Paper Series 4061, CESifo Group Munich.

Brollo, F., Nannicini, T. (2012). "Tying Your Enemy's Hands in Close Races: The Politics of Federal Transfers in Brazil," American Political Science Review, 106 742-761.

Brollo, F., Nannicini, T., Perotti, R. and Tabellini, G. (2013). "The Political Resource Curse," American Economic Review, 103(5), 1759-96.

Case, A. (2001). "Election goals and income redistribution: Recent evidence from Albania," European Economic Review, 45 (3), 405-423.

Cioffi, M., Messina, G., Tommasino, P. (2012), Parties, institutions and political budget cycles at the municipal level, Temi di discussione (Economic working papers) 885, Bank of Italy, Economic Research and International Relations Area.

Cox, G. W., McCubbins, M. D. (1986). "Electoral Politics as a Redistributive Game," The Journal of Politics, 8 (2), 370-389. 
Dahlberg, M., Mörk, E., Rattsø, J., Ågren, H. (2008) "Using a discontinuous grant rule to identify the effect of grants on local taxes and spending," Journal of Public Economics, 92 (12), 2320-2335.

Dixit, A., Londregan, J. (1995). 'Redistributive politics and Economic Efficiency," American Political Science Review, 9, 856-66.

Dixit, A., Londregan, J. (1998). "Fiscal federalism and redistributive politics," Journal of Public Economics, 68 (2), 153-180.

Ferreira, F., Gyourko, J. (2009). "Do Political Parties Matter? Evidence from U.S. Cities," The Quarterly Journal of Economics, 124 (1), 399-422.

Fiorina, M. P. (1978). "Economic Retrospective Voting in American National Elections: A MicroAnalysis " American Journal of Political Science, 22 (2), pp. 426-443.

Hamilton, B. W. (1983). "The flypaper effect and other anomalies," Journal of Public Economics, 22 (3), 347-361.

Imbens G., Kalyanaraman K. (2009). "Optimal Bandwidth Choice for the Regression Discontinuity Estimator," Review of Economic Studies, 79(3), 933-959.

Imbens, G. W., Lemieux, T. (2008). "Regression discontinuity designs: A guide to practice," Journal of Econometrics, 142(2), 615-635.

Inman, R. P. (2008). The flypaper effect, NBER Working Paper No. 14579, National Bureau of Economic Research.

Johansson, E. (2003), "Intergovernmental grants as a tactical instrument: empirical evidence from Swedish municipalities," Journal of Public Economics, 87 (5-6), 883-915.

Knight, B. (2002). "Endogenous Federal Grants and Crowd-out of State Government Spending: Theory and Evidence from the Federal Highway Aid Program," American Economic Review, September 2002, $92(1), 71-92$.

Larcinese, V., Rizzo, L., Testa, C. (2006). "Allocating the U.S. Federal Budget to the States: The Impact of the President," The Journal of Politics, 68, 447-456.

Lee, D. S. (2001). The Electoral Advantage to Incumbency and Voters' Valuation of Politicians' Experience: A Regression Discontinuity Analysis of Elections to the U.S.., NBER Working Papers 8441, National Bureau of Economic Research.

Lee, D. S. (2008)."Randomized experiments from non-random selection in U.S. House elections," Journal of Econometrics, 142 (2), 675-697.

Lee, D. S., Lemieux, T. (2010). "Regression Discontinuity Designs in Economics," Journal of Economic Literature, 48 (2), 281-355.

Lee, D. S., Moretti, E., Butler, M. J. (2004). "Do Voters Affect or Elect Policies? Evidence from the U. S. House," The Quarterly Journal of Economics, 119 (3), 807-859. 
Levitt, S. D., Snyder, Jr., J.M. (1995). "Political parties and the distribution of federal outlays," American Journal of Political Science, 39, 958-980.

Lindbeck, A., Weibull, J.W. (1987). "Balanced-budget redistribution as the outcome of political competition," Public Choice, 52, 273-297.

McCrary, J. (2008). "Manipulation of the running variable in the regression discontinuity design: A density test," Journal of Econometrics, 142(2), 698-714.

Migueis, M. (2013). "The Effect of Political Alignment on Transfers to Portuguese Municipalities, " Economics and Politics, March 2013, 25(1), 110-133.

Persson, T., Tabellini, G. (2000). Political Economics: Explaining Economic Policy, MIT Press.

Pettersson-Lidbom, P. (2008). "Do Parties Matter for Economic Outcomes? A Regression-Discontinuity Apprach," Journal of the European Economic Association, 6 (5), 1037-1056.

Rodden, J., Wilkinson, S. (2004), The shifting political economy of redistribution in the Indian Federation, Technical Report, MIT.

Solé-Ollé, A., Sorribas-Navarro, P. (2008). "The effects of partisan alignment on the allocation of intergovernmental transfers. Differences-in-differences estimates for Spain," Journal of Public Economics, 92 (12), 2302-2319.

Staiger, D. and J.H. Stock (1997): "Instrumental Variables Regression with Weak Instruments," Econometrica, 65, $557-586$.

Wolfers, J., (2002). Are Voters Rational? Evidence from Gubernatorial Elections, Research Papers 1730, Stanford University, Graduate School of Business.

\section{Appendix}

Insert Table A1-3 about here

Insert Figure A1 about here 


\section{Tables}

Table 1. Party affiliation of mayors in all elections (1998-2008)

\begin{tabular}{l|rr|rr|rc}
\hline \hline & \multicolumn{2}{|c|}{ All municipalities } & \multicolumn{2}{|c|}{ Only $<15000$} & \multicolumn{2}{|c}{ Only $>15000$} \\
& \multicolumn{1}{|c|}{ No. } & \multicolumn{1}{c|}{$\%$} & \multicolumn{1}{c}{ No. } & \multicolumn{1}{c}{ No. } & \multicolumn{1}{c}{$\%$} \\
\hline Center-left & 20,641 & 23.69 & 16,588 & 20.68 & 4,053 & 58.54 \\
Center-right & 13,413 & 15.39 & 10,924 & 13.62 & 2,489 & 35.95 \\
Independents (Lista civica) & 53,015 & 60.84 & 52,639 & 65.62 & 376 & 5.43 \\
Missing & 75 & 0.09 & 70 & 0.09 & 5 & 0.07 \\
\hline Total & 87,144 & & 80,221 & & 6,923 \\
\hline \hline
\end{tabular}

Note. The table reports statistics on mayors' party affiliation on annual basis for the period 1998-2008.

Table 2. Distribution of elections by aligned and non-aligned municipalities (regression sample)

\begin{tabular}{c|ccc|ccc|c}
\hline \hline \multirow{2}{*}{ year } & \multicolumn{3}{|c|}{ Aligned } & \multicolumn{3}{|c|}{ Not Aligned } & Total \\
& Center-right & Center-left & Total & $\begin{array}{c}\text { Center- } \\
\text { right }\end{array}$ & Center-left & $\begin{array}{c}\text { Tota } \\
l\end{array}$ & election \\
\hline 1998 & 0 & 23 & 23 & 21 & 0 & 21 & 44 \\
1999 & 0 & 122 & 122 & 47 & 0 & 47 & 169 \\
2000 & 0 & 26 & 26 & 19 & 0 & 19 & 45 \\
2001 & 47 & 0 & 47 & 0 & 42 & 42 & 89 \\
2002 & 59 & 0 & 59 & 0 & 68 & 68 & 127 \\
2003 & 17 & 0 & 17 & 0 & 29 & 29 & 46 \\
2004 & 43 & 0 & 43 & 0 & 144 & 144 & 187 \\
2005 & 18 & 0 & 18 & 0 & 45 & 45 & 63 \\
2006 & 0 & 62 & 62 & 44 & 0 & 44 & 106 \\
2007 & 0 & 42 & 42 & 75 & 0 & 75 & 117 \\
2008 & 34 & 0 & 34 & 0 & 23 & 23 & 57 \\
\hline Total & 218 & 275 & 493 & 206 & 351 & 557 & 1050 \\
\hline \hline
\end{tabular}

Table 3. Descriptive statistics, observations in the regression sample

\begin{tabular}{l|c|c|c}
\hline \hline & All & $M V$ & $M V$ \\
& sample & $<5 \%$ & $<2 \%$ \\
\hline Aligned & 2,312 & 265 & 116 \\
Not Aligned & 2,447 & 271 & 105 \\
\hline Total & 4,759 & 536 & 221 \\
\hline \hline
\end{tabular}


Table 4. Descriptive statistics, means and standard deviations by margin of alignment (regression sample)

\begin{tabular}{|c|c|c|c|c|c|c|}
\hline & \multicolumn{3}{|c|}{ Mean } & \multicolumn{3}{|c|}{ Std. Dev. } \\
\hline & $\begin{array}{c}\text { All } \\
\text { sample }\end{array}$ & $\begin{array}{c}M V \\
<5 \% \\
\end{array}$ & $\begin{array}{l}M V \\
<2 \% \\
\end{array}$ & $\begin{array}{c}\text { All } \\
\text { sample }\end{array}$ & $\begin{array}{l}M V \\
<5 \% \\
\end{array}$ & $\begin{array}{l}M V \\
<2 \% \\
\end{array}$ \\
\hline $\begin{array}{l}\text { Current grants from central } \\
\text { government, real euro per-capita }\end{array}$ & 154.71 & 162.65 & 152.17 & 91.88 & 92.98 & 91.79 \\
\hline $\begin{array}{l}\text { Current grants from regional } \\
\text { government, real euro per-capita }\end{array}$ & 45.56 & 47.26 & 46.45 & 41.24 & 46.08 & 52.83 \\
\hline $\begin{array}{l}\text { Total municipal taxes (property }+ \\
\text { income tax) - real euro per capita }\end{array}$ & 243.96 & 229.20 & 250.72 & 85.63 & 79.75 & 69.77 \\
\hline $\begin{array}{l}\text { Current municipal fees } \\
\text { real euro per-capita }\end{array}$ & 268.55 & 257.54 & 274.12 & 142.00 & 134.68 & 149.02 \\
\hline $\begin{array}{l}\text { Current municipal expenditure } \\
\text { real euro per-capita }\end{array}$ & 790.57 & 764.97 & 797.97 & 203.71 & 202.18 & 183.81 \\
\hline $1=$ if incumbent mayor is re-elected & 0.7896 & 0.6521 & 0.5010 & 0.4078 & 0.4797 & 0.5107 \\
\hline $1=$ if incumbent party is re-elected & 0.8028 & 0.6782 & 0.5294 & 0.3982 & 0.4699 & 0.5066 \\
\hline $\begin{array}{l}1=\text { if mayor elected at the second } \\
\text { round }\end{array}$ & 0.4406 & 0.9085 & 0.9049 & 0.4965 & 0.2884 & 0.2939 \\
\hline Margin of victory, municipal election & 21.82 & 2.53 & 1.02 & 14.96 & 1.47 & 0.54 \\
\hline $\begin{array}{l}1=\text { if municipality is aligned with the } \\
\text { central government }\end{array}$ & 0.4858 & 0.4944 & 0.5249 & 0.4999 & 0.5004 & 0.5005 \\
\hline $\begin{array}{l}1=\text { if municipality is aligned with the } \\
\text { regional government }\end{array}$ & 0.5999 & 0.4384 & 0.5294 & 0.4899 & 0.4966 & 0.5000 \\
\hline Resident population & 55,292 & 76,601 & 48,489 & 151,946 & 273,192 & 68,768 \\
\hline $\begin{array}{l}\text { Percentage of residents under } 15 \text { years } \\
\text { old }\end{array}$ & 14.57 & 15.05 & 14.11 & 3.17 & 3.64 & 2.87 \\
\hline $\begin{array}{l}\text { Percentage of residents over } 65 \text { years } \\
\text { old }\end{array}$ & 17.54 & 16.90 & 17.96 & 4.53 & 4.49 & 4.26 \\
\hline $\begin{array}{l}\text { Income different form real estate, real } \\
\text { euro per-capita }\end{array}$ & 16,851 & 16,873 & 17,590 & 3,263 & 3,409 & 3,083 \\
\hline $\begin{array}{l}\text { Income from real estate, real euro per- } \\
\text { capita }\end{array}$ & 1,777 & 1,769 & 1,821 & 521 & 514 & 551 \\
\hline $\begin{array}{l}\text { Electoral cycle }(0=\text { election year, } \\
4 \text { = year before election })\end{array}$ & 1.84 & 1.84 & 1.77 & 1.37 & 1.38 & 1.37 \\
\hline $\begin{array}{l}\text { Local government dummy } \\
\text { (1 = left council) }\end{array}$ & 0.6090 & 0.4683 & 0.4661 & 0.4880 & 0.4995 & 0.5000 \\
\hline $\begin{array}{l}\text { Central government dummy } \\
(1=\text { left central government })\end{array}$ & 0.3137 & 0.3060 & 0.2805 & 0.4641 & 0.4612 & 0.4503 \\
\hline
\end{tabular}

Note. Number of observations: All sample $=4,759 ; \mathrm{MV}<5 \%=536 ; \mathrm{MV}<5 \%=221$. 
Table 5. Political alignment and grant allocation

\begin{tabular}{|c|c|c|c|c|}
\hline Regression specifications & $\begin{array}{c}\text { No } \\
\text { Controls }\end{array}$ & $\begin{array}{l}\text { With } \\
\text { Controls }\end{array}$ & $\begin{array}{l}\text { With controls \& } \\
\text { Fixed Effect }\end{array}$ & Observations \\
\hline $\begin{array}{l}\text { OLS regression (all } \\
\text { sample) }\end{array}$ & $\begin{array}{l}0.555^{* * *} \\
(0.0324)\end{array}$ & $\begin{array}{l}0.138^{* * *} \\
(0.0218)\end{array}$ & $\begin{array}{l}0.134 * * * \\
(0.0314)\end{array}$ & 3546 \\
\hline $\begin{array}{l}\text { OLS regression (all } \\
\text { sample, } 2 \text { nd round) }\end{array}$ & $\begin{array}{l}0.386^{* * *} \\
(0.0523)\end{array}$ & $\begin{array}{l}0.143^{* * *} \\
(0.0343)\end{array}$ & $\begin{array}{l}0.131^{* * *} \\
(0.0444)\end{array}$ & 1431 \\
\hline $\begin{array}{l}\text { Fourth order polynomial } \\
\text { (RD Sample) }\end{array}$ & $\begin{array}{l}0.475^{* * *} \\
(0.157)\end{array}$ & $\begin{array}{l}0.364^{* * *} \\
-0.105\end{array}$ & $\begin{array}{l}0.365^{* * *} \\
(0.137)\end{array}$ & 3141 \\
\hline $\begin{array}{l}\text { Fourth order polynomial } \\
\text { (RD Sample, 2nd round) }\end{array}$ & $\begin{array}{l}0.713^{* * *} \\
(0.219)\end{array}$ & $\begin{array}{l}0.588 * * * \\
(0.147)\end{array}$ & $\begin{array}{l}0.523^{* * *} \\
(0.195)\end{array}$ & 1263 \\
\hline $\begin{array}{l}\text { Local Linear regression } \\
\text { (h) }\end{array}$ & $\begin{array}{l}0.326^{* * *} \\
(0.120)\end{array}$ & $\begin{array}{l}0.403^{* * *} \\
(0.121)\end{array}$ & $\begin{array}{l}0.439 * * * \\
(0.0930)\end{array}$ & 856 \\
\hline $\begin{array}{l}\text { Local linear regression } \\
\text { (half } \mathrm{h} \text { ) }\end{array}$ & $\begin{array}{l}0.174 \\
(0.183)\end{array}$ & $\begin{array}{l}0.449 * * \\
(0.182)\end{array}$ & $\begin{array}{l}0.301^{* *} \\
(0.137)\end{array}$ & 324 \\
\hline $\begin{array}{l}\text { Local linear regression } \\
\text { (double h) }\end{array}$ & $\begin{array}{l}0.319 * * * \\
(0.0792)\end{array}$ & $\begin{array}{l}0.348^{* * *} \\
(0.0838)\end{array}$ & $\begin{array}{l}0.303^{* * *} \\
(0.0643)\end{array}$ & 1750 \\
\hline
\end{tabular}

Notes. The table reports coefficients on alignment dummies. RD sample included all municipal elections where the winner and the runner up belong to the centre-left and centre-right coalition. Controls include: municipal population and population squared, income per capita, income per capita from real estate, proportion of population under 14 and over 65 years old. Time dummies are included in all regressions in columns 2 and 3. Optimally chosen bandwidth $(\mathrm{h})$ in local linear regressions is $+/-13$. Significance at $1 \%$ is represented by *** , at $5 \%$ by ** and at $10 \%$ by *. Robust standard errors in brackets clustered at municipal level. The number of observations drops from 3546 to 3141 because the lagged margin of victory is missing for the first year of the dataset since we do not have election data for the year 1997. 
Table 6. Alignment and the probability of incumbent re-election

\begin{tabular}{|c|c|c|c|c|c|c|c|c|}
\hline \multirow{2}{*}{$\begin{array}{l}\text { Coefficient on } \\
\text { Alignment }\end{array}$} & \multicolumn{3}{|c|}{ Panel 1: Incumbent Party } & \multirow[b]{2}{*}{ Obs. } & \multicolumn{3}{|c|}{ Panel 2: Incumbent Candidate } & \multirow[b]{2}{*}{ Obs. } \\
\hline & $\begin{array}{c}\text { No } \\
\text { controls }\end{array}$ & Controls & $\begin{array}{l}\text { Controls } \\
\text { \& FE }\end{array}$ & & $\begin{array}{c}\text { No } \\
\text { controls }\end{array}$ & Controls & $\begin{array}{l}\text { Controls } \\
\& \mathrm{FE}\end{array}$ & \\
\hline Linear regression & $\begin{array}{c}0.0279 \\
(0.0275)\end{array}$ & $\begin{array}{l}0.144^{* * *} \\
(0.0378)\end{array}$ & $\begin{array}{l}0.156^{* * *} \\
(0.0359)\end{array}$ & 768 & $\begin{array}{l}0.156^{* * *} \\
(0.0373)\end{array}$ & $\begin{array}{l}0.119^{* * *} \\
(0.0433)\end{array}$ & $\begin{array}{l}0.128^{* * *} \\
(0.042)\end{array}$ & 641 \\
\hline $\begin{array}{l}\text { Second order } \\
\text { polynomial (RD Sample) }\end{array}$ & $\begin{array}{c}0.208 \\
(0.130)\end{array}$ & $\begin{array}{l}0.312^{* * *} \\
(0.101)\end{array}$ & $\begin{array}{l}0.267^{* * *} \\
(0.101)\end{array}$ & 363 & $\begin{array}{l}0.358^{* *} \\
(0.140)\end{array}$ & $\begin{array}{l}0.314^{* *} \\
(0.134)\end{array}$ & $\begin{array}{l}0.256^{*} \\
(0.141)\end{array}$ & 205 \\
\hline $\begin{array}{l}\text { Local Linear regression } \\
\text { (h) }\end{array}$ & $\begin{array}{l}0.759 * * \\
(0.356)\end{array}$ & $\begin{array}{c}0.521 \\
(0.468)\end{array}$ & & 26 & $\begin{array}{l}0.623 * \\
(0.357)\end{array}$ & $\begin{array}{c}0.119 \\
(0.428)\end{array}$ & & 22 \\
\hline $\begin{array}{l}\text { Local linear regression } \\
\text { (half } \mathrm{h} \text { ) }\end{array}$ & $\begin{array}{l}0.840^{* *} \\
(0.387)\end{array}$ & $\begin{array}{c}0.838 \\
(0.828)\end{array}$ & & 17 & $\begin{array}{c}0.714 \\
(0.470)\end{array}$ & $\begin{array}{c}0.778 \\
(0.631)\end{array}$ & & 15 \\
\hline $\begin{array}{l}\text { Local linear regression } \\
\text { (double h) }\end{array}$ & $\begin{array}{l}0.631^{* *} \\
(0.290)\end{array}$ & $\begin{array}{l}0.715^{* *} \\
(0.356)\end{array}$ & & 42 & $\begin{array}{l}0.611^{*} \\
(0.300)\end{array}$ & $\begin{array}{c}0.303 \\
(0.282)\end{array}$ & & 33 \\
\hline
\end{tabular}

Notes. The table reports coefficients on alignment dummies. RD sample included all municipal elections where the winner and the runner up belong to the centre-left and centre-right coalition. Controls include: municipal population and population squared, income per capita, income per capita from real estate, proportion of population under 14 and over 65 years old. Time dummies are included in all regressions in columns 2 and 3, 5 and 6 . Optimally chosen bandwidth (h) in local linear regressions is $+/-3.5 \%$. Significance at $1 \%$ is represented by $* * *$, at $5 \%$ by ** and at $10 \%$ by ${ }^{*}$. Robust standard errors in brackets clustered at municipal level. The number of observations drops from 641 to 205 because the lagged margin of victory is missing for the first year of the dataset since we do not have election data for the year 1997. 
Table 7- Testing for flypaper effect, determination of municipal taxes (Euros per capita)

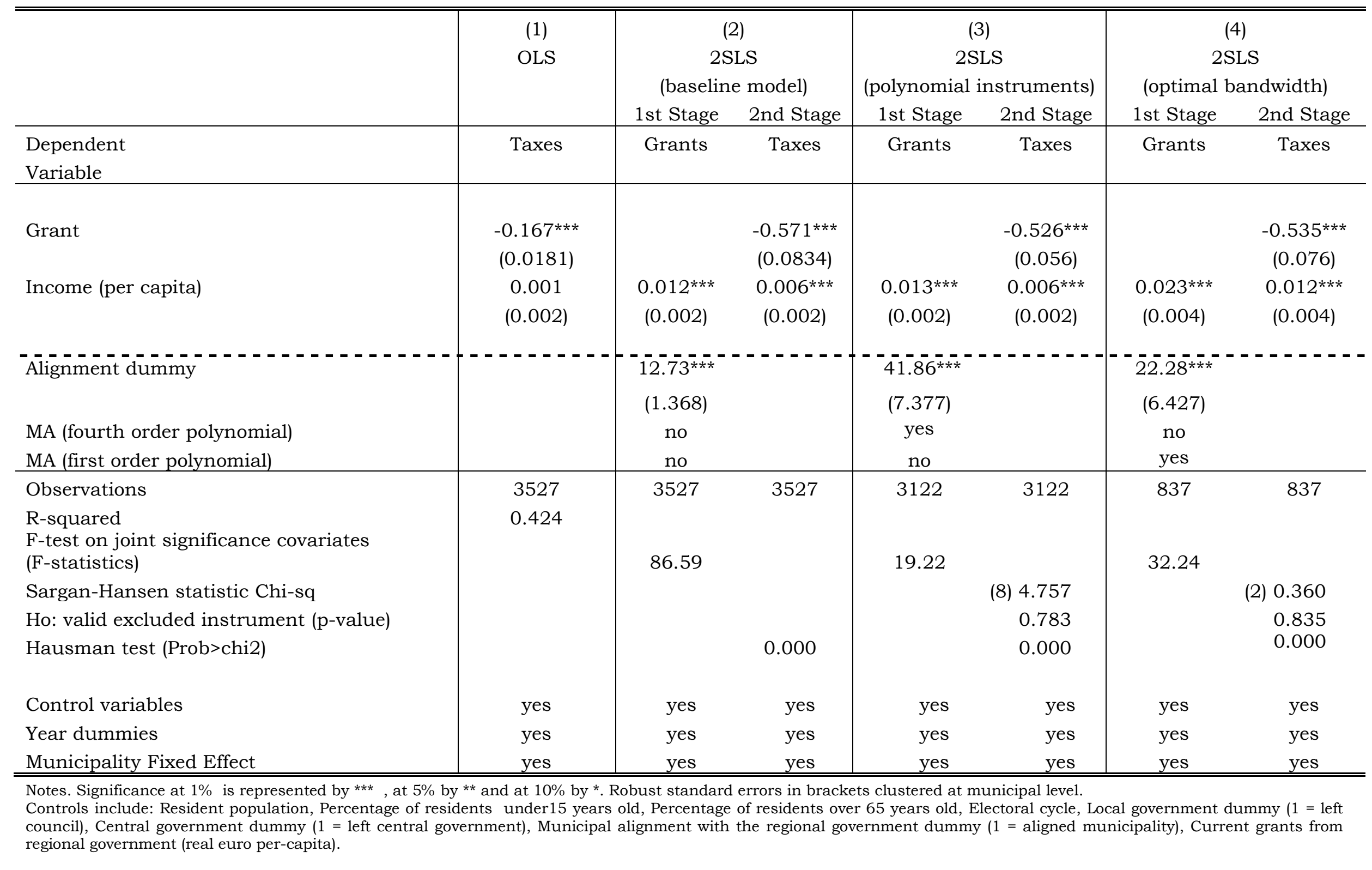


Table A1. AIC and Goodness of Fit tests for grants and Incumbent regressions

\begin{tabular}{c|cc|cc|cc}
\hline \hline \multirow{2}{*}{$\begin{array}{c}\text { Polynomial } \\
\text { Grade }\end{array}$} & \multicolumn{2}{|c|}{ Grants } & \multicolumn{2}{c|}{$\begin{array}{c}\text { Incumbent } \\
\text { (Party) }\end{array}$} & \multicolumn{2}{c}{$\begin{array}{c}\text { Incumbent } \\
\text { (Candidate) }\end{array}$} \\
& F-test & AIC & F-test & AIC & F-test & AIC \\
\hline 0 & 0.0883 & 3450.742 & 0.0969 & 596.109 & 0.5605 & 56.384 \\
1 & 0.2128 & 3451.338 & 0.3802 & 599.719 & 0.5576 & 59.812 \\
2 & 0.2322 & 3451.204 & $\underline{0.7173}$ & $\underline{603.011}$ & $\underline{0.6727}$ & $\underline{63.411}$ \\
3 & 0.2866 & 3454.528 & 0.7893 & 605.798 & 0.7333 & 67.104 \\
4 & $\underline{0.2563}$ & $\underline{3448.634}$ & 0.9586 & 606.434 & 0.9156 & 69.986 \\
5 & 0.2345 & 3451.392 & 0.9388 & 599.423 & 0.8051 & 65.674 \\
6 & 0.3804 & 3448.036 & 0.9226 & 595.748 & 0.8230 & 63.592 \\
\hline \hline
\end{tabular}

Table A2. Testing for the continuity of the covariates in close elections

\begin{tabular}{c|c|c}
\hline \hline $\begin{array}{c}\text { Polynomial } \\
\text { Grade }\end{array}$ & Chi2(12) & Prob > Chi2 \\
\hline 0 & 27.18 & 0.0073 \\
1 & 17.27 & 0.1396 \\
2 & 16.89 & 0.1538 \\
3 & 26.3 & 0.0097 \\
4 & 20.87 & 0.0523 \\
5 & 15.55 & 0.2127 \\
6 & 15.57 & 0.2115 \\
\hline \hline
\end{tabular}

Notes. The table reports chi-square tests for the discontinuity gaps to examine whether the covariates in the RD do not exhibit any discontinuity in relation to the margin of alignment. As suggested by Lee and Lemieux (2010) we test the null of discontinuities in all covariates simultaneously estimating a Seemingly Unrelated Regression (SUR) where each equation represents a different baseline covariate. 
Table A3. Testing the interaction between alignment and electoral cycle on grants

\begin{tabular}{|c|c|c|c|c|}
\hline \multirow[b]{2}{*}{ alignment dummy } & \multicolumn{2}{|c|}{ OLS regression } & \multicolumn{2}{|c|}{$\begin{array}{c}\text { Fourth polynomial } \\
\text { order } \\
\text { (RD sample) }\end{array}$} \\
\hline & $\begin{array}{l}0.087^{* *} \\
(0.039)\end{array}$ & $\begin{array}{l}0.089 * * \\
(0.036)\end{array}$ & $\begin{array}{l}0.311^{* *} \\
(0.139)\end{array}$ & $\begin{array}{l}0.329 * * \\
(0.144)\end{array}$ \\
\hline Electoral cycle & $\begin{array}{c}0.005 \\
(0.012)\end{array}$ & & $\begin{array}{c}0.006 \\
(0.012) \\
\end{array}$ & \\
\hline $\begin{array}{l}\text { Alignment dummy } \\
\text { X Electoral cycle }\end{array}$ & $\begin{array}{l}0.025^{*} \\
(0.013)\end{array}$ & & $\begin{array}{l}0.027^{*} \\
(0.015) \\
\end{array}$ & \\
\hline Electoral cycle 2 & & $\begin{array}{l}-0.009 \\
(0.045)\end{array}$ & & $\begin{array}{l}-0.002 \\
(0.045)\end{array}$ \\
\hline $\begin{array}{l}\text { Alignment dummy } \\
\text { X Electoral cycle } 2\end{array}$ & & $\begin{array}{l}0.110^{* *} \\
(0.055)\end{array}$ & & $\begin{array}{l}0.109 * \\
(0.056)\end{array}$ \\
\hline $\begin{array}{l}\text { Controls } \\
\text { Year FE } \\
\text { Municipal FE } \\
\text { No. of observations }\end{array}$ & $\begin{array}{l}\text { Yes } \\
\text { Yes } \\
\text { Yes } \\
3546 \\
\end{array}$ & $\begin{array}{l}\text { Yes } \\
\text { Yes } \\
\text { Yes } \\
3546 \\
\end{array}$ & $\begin{array}{l}\text { Yes } \\
\text { Yes } \\
\text { Yes } \\
3141 \\
\end{array}$ & $\begin{array}{l}\text { Yes } \\
\text { Yes } \\
\text { Yes } \\
3141 \\
\end{array}$ \\
\hline
\end{tabular}

Notes. Significance at $1 \%$ is represented by $* * *$, at $5 \%$ by ** and at $10 \%$ by * Robust standard errors in brackets clustered at municipal level. Here, "e" denotes election year. Electoral cycle 2 is a dummy = 1 in year before election only. In columns 3 and 4, the number of observations drops from 3546 to 3141 because the lagged margin of victory is missing for the first year of the dataset since we do not have election data for the year 1997. 


\section{Figures}

Figure 1. Yearly distribution of municipalities by winning coalitions

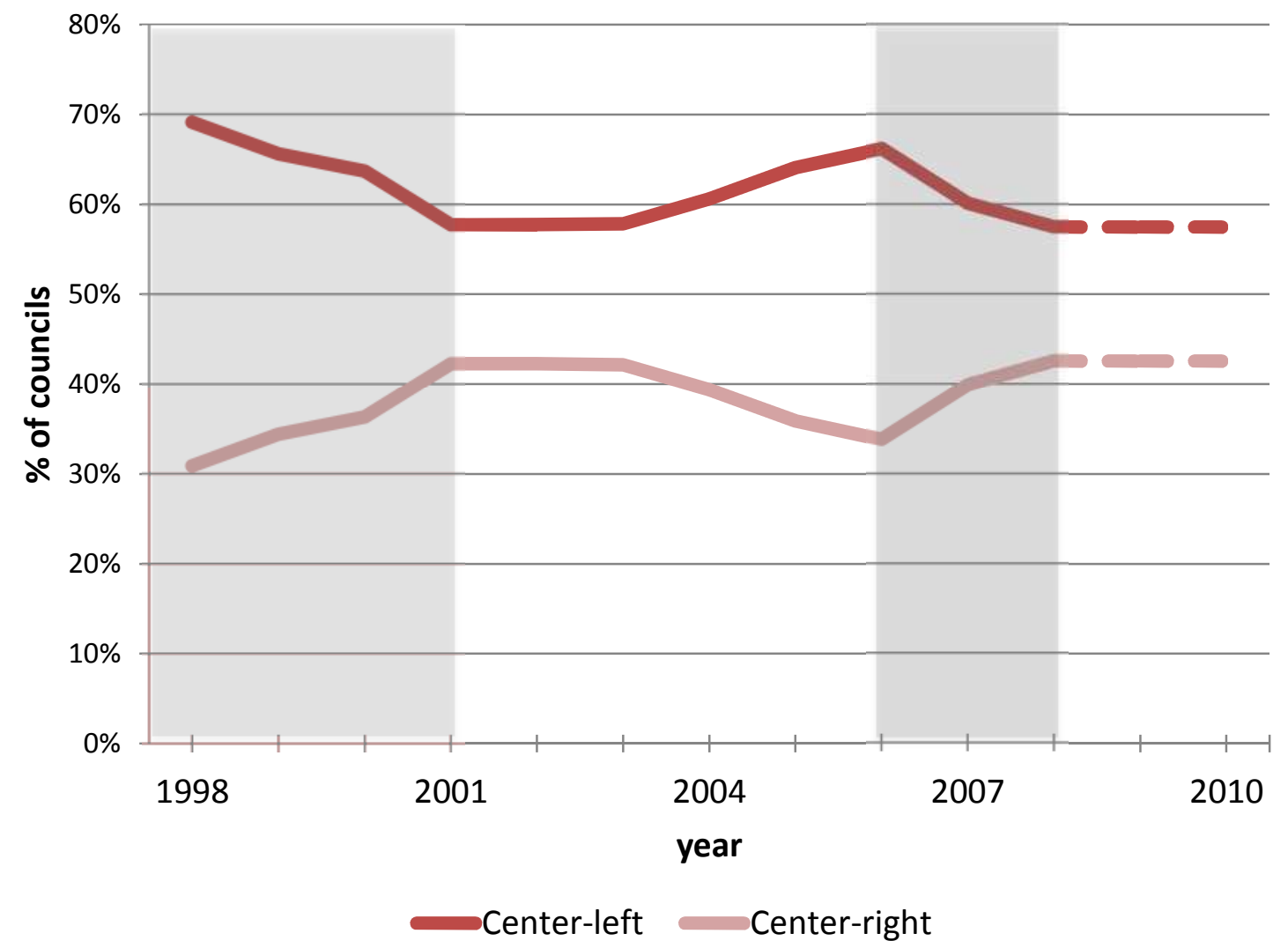

Notes: electoral data covers the 1998-2008 period, however we retain in the dataset municipalities without mayoral election between in 2009 and 2010. The (un)shaded areas refer to years when a central-left (right) government was in power. 
Figure 2. Grants

(a) - all sample

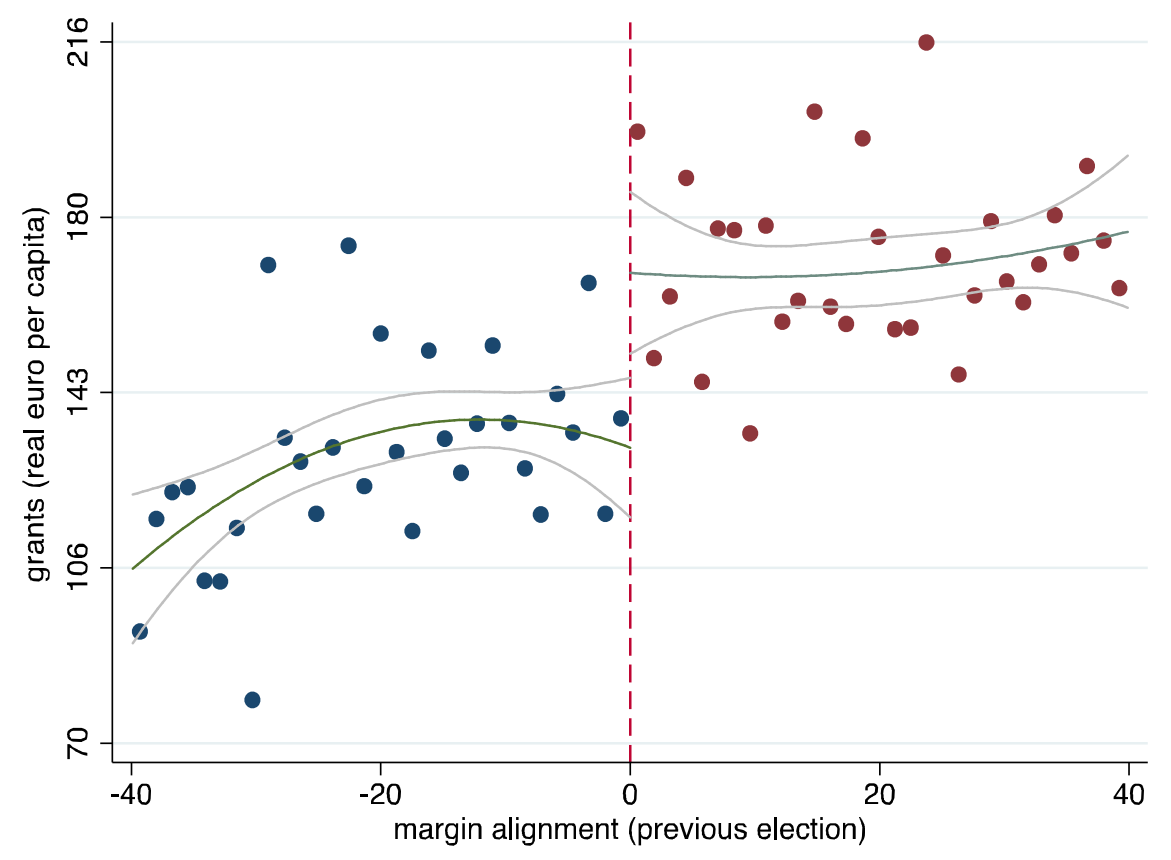

(b) - optimal bandwidth

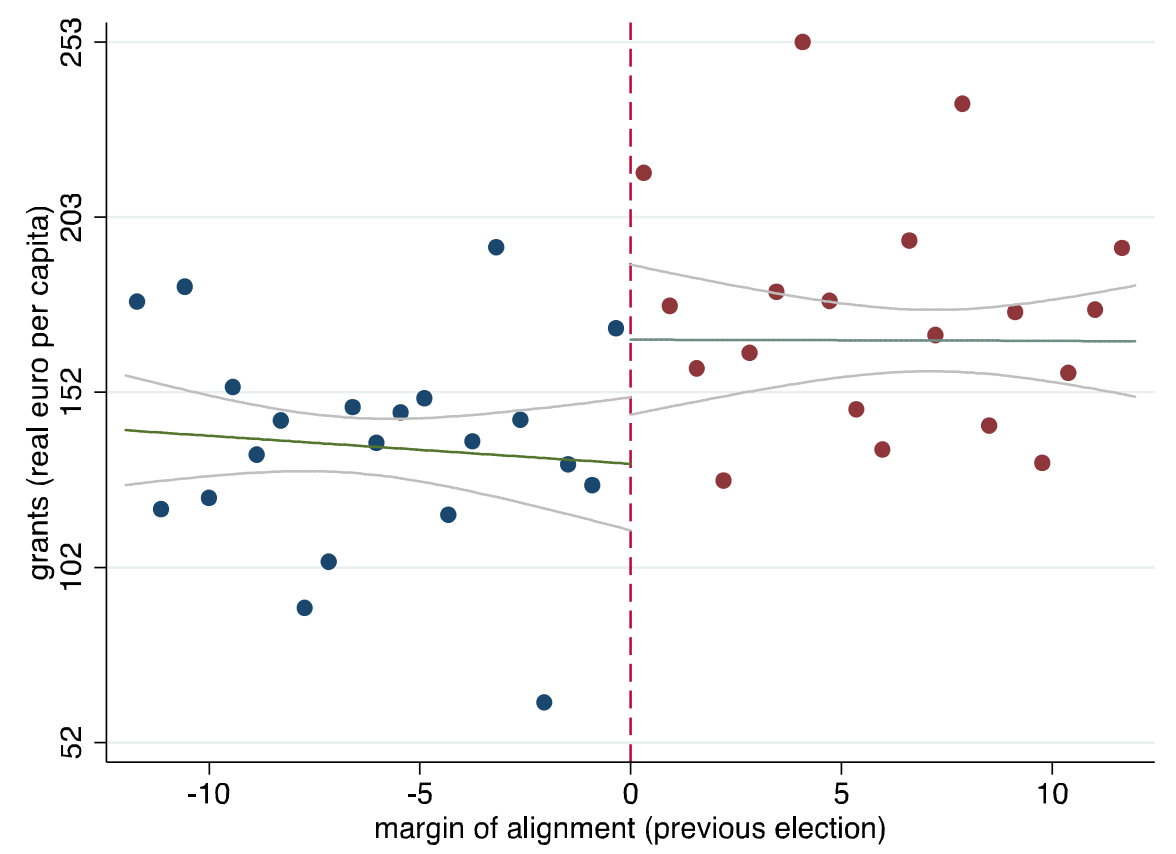

Notes. The central line split the polynomial functions in the margin of alignment fitted over the interval $[-40,+40]$ in panel (a), and over the optimal bandwidth in panel (b). The lateral lines represent the $95 \%$ confidence interval. Scatter points are averaged over 2-unit intervals. 
Figure 3. Probability of re-election

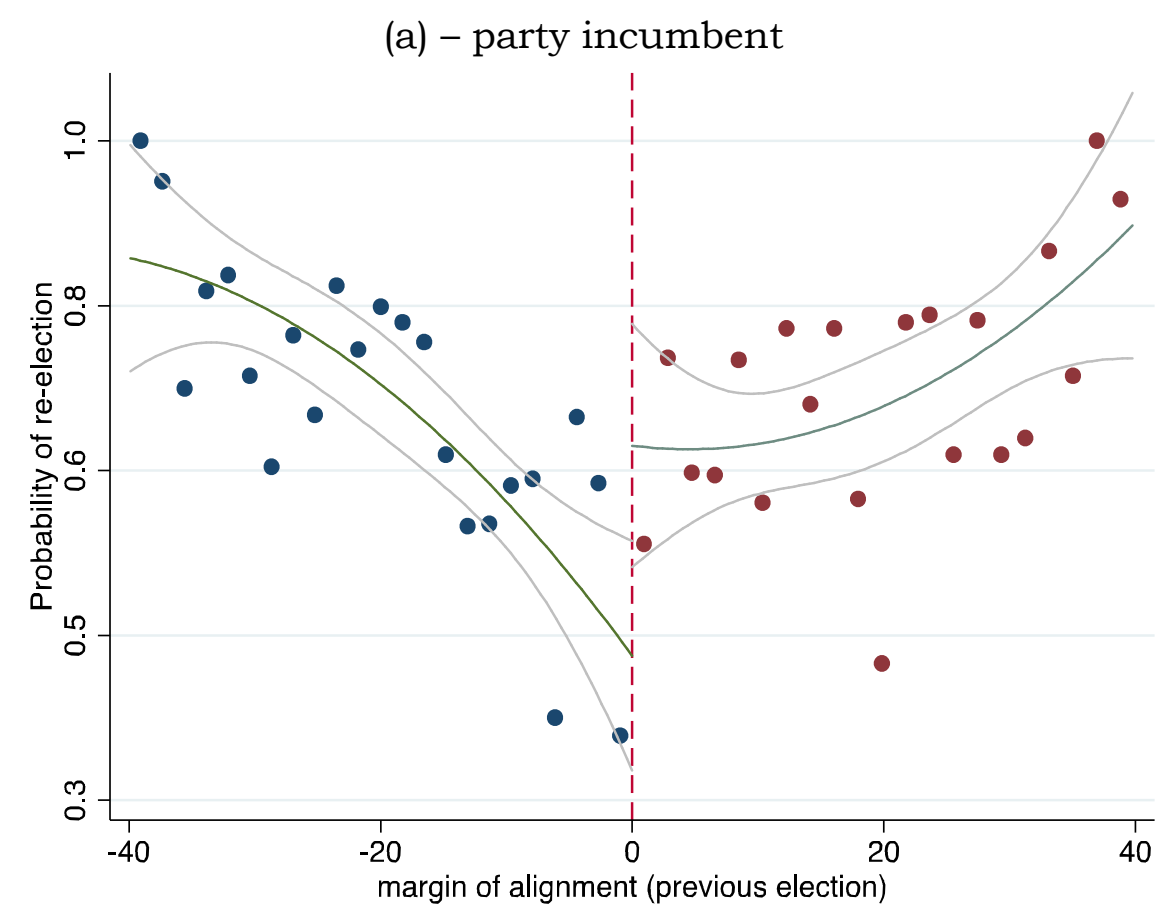

(b) - candidate incumbent

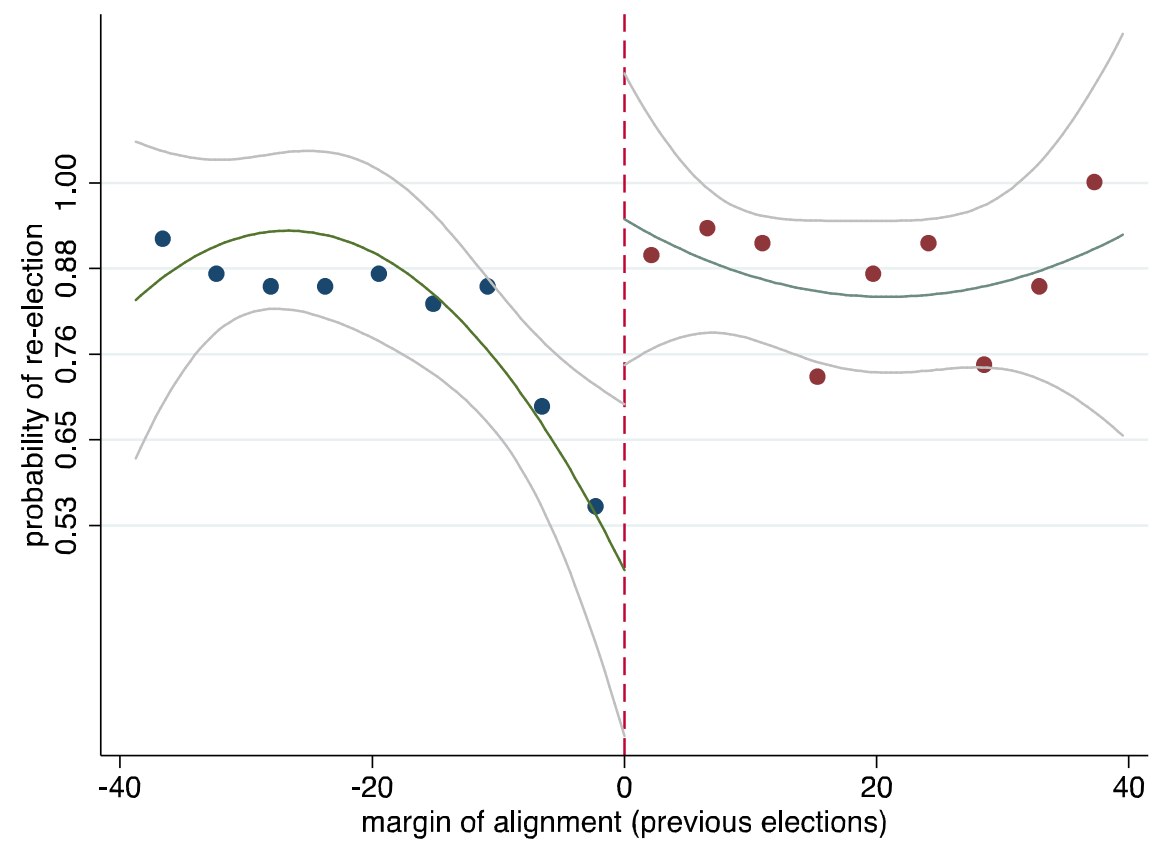

Notes. The central line split the polynomial function in the margin of alignment fitted over the interval $[-40,+40]$. The lateral lines represent the 95\% confidence interval. Scatter points are averaged over 2-unit intervals. 
Figure A1. Density of the forcing variable

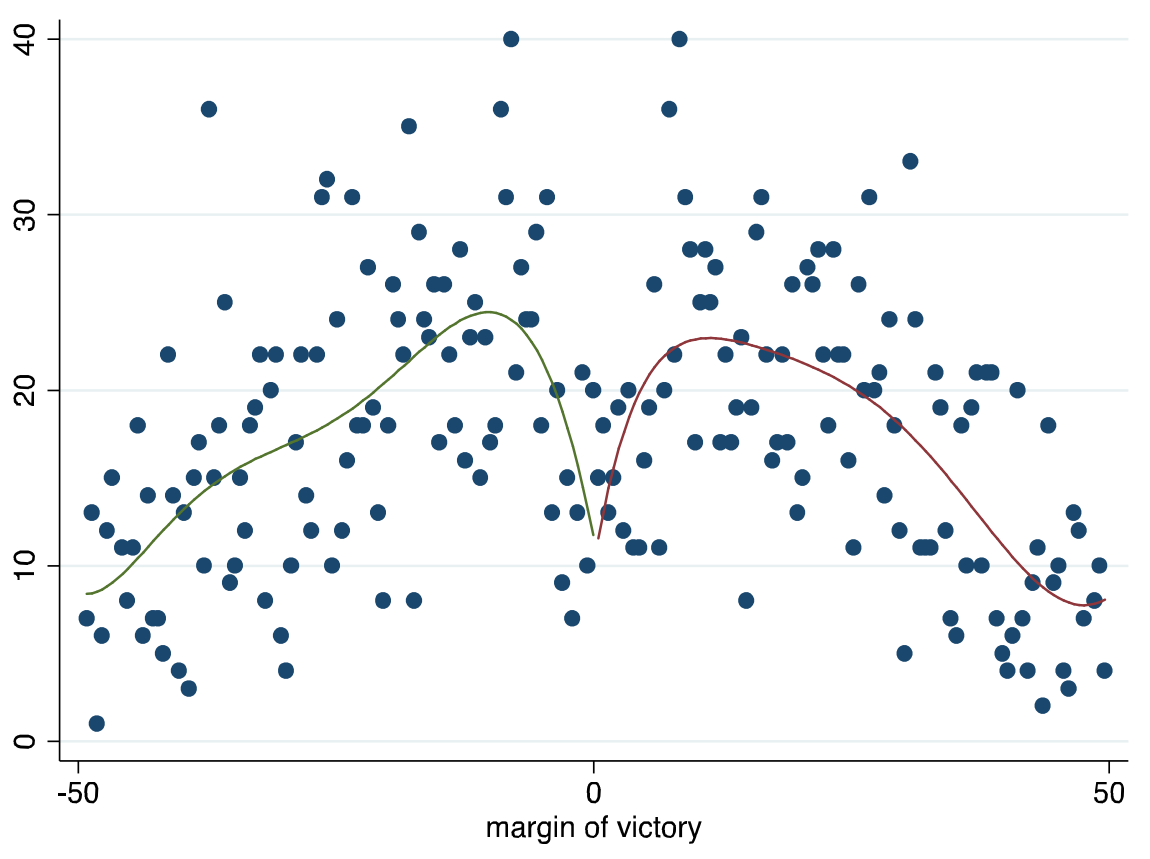

Notes. The figure shows a graph of the raw densities computed over bins with a bandwidth of 0.01 (100 bins in the graph), along with a smooth 4th-order polynomial model. 


\section{Online Appendix}

\section{Second-Period Equilibrium and Derivation of the Continuation Value $V$}

In the second period, the incumbent politician in $i$ chooses $\tau_{i}, e_{i}$ to maximize $\lambda\left(f\left(\tau_{i}+T_{i}\right)+e_{i}+a_{i}^{e}-\right.$ $\left.d\left(\tau_{i}\right)\right)-\psi\left(e_{i}\right)$ taking $T_{i}$ as given, where $a_{i}^{e}$ is the expected value of $a_{i}$ conditional on the incumbent's information set at the beginning of period 2 (if the period 1 incumbent wins the election, he has enough information to calculate $a_{i}$ i.e. $a_{i}^{e}=a_{i}$, but if the challenger wins the election, $\left.a_{i}^{e}=0\right)$. The first-order conditions are

$$
\lambda=\psi^{\prime}\left(e_{i}\right), f^{\prime}\left(\tau_{i}+T_{i}\right)=d^{\prime}\left(\tau_{i}\right)
$$

At the same time, the national government chooses $T_{i}$ to maximize

$$
\sum_{i \in M} \lambda\left(f\left(\tau_{i}+T_{i}\right)+e_{i}+a_{i}^{e}-d\left(\tau_{i}\right)\right)-\sum_{i \in M} T_{i}
$$

taking $\tau_{i}, e_{i}$ as given. So, at equilibrium, the first-order conditions with respect to $T_{i}$ are

$$
\lambda f^{\prime}\left(\tau_{i}+T_{i}\right)=1, i \in M
$$

Clearly, all these first-order conditions are identical across municipalities. We assume for convenience that these conditions have the unique solution $\hat{\tau}, \hat{e}, \hat{T}$. Then, the continuation value to the incumbent of winning the election, from the perspective of the beginning of period 2 , is

$$
\lambda\left(f(\hat{\tau}+\hat{T})+e+a_{i}^{e}-d(\hat{\tau})\right)-\psi(\hat{e}) \equiv V+\lambda a_{i}
$$

Now, at the time of choosing policy before the election in period 1, neither the incumbent in $i$ nor the national government have observed $a_{i}$, or any variable correlated with it, so their expectation of the continuation value is simply $V$.

Proof of Proposition 2. First, note that $T_{i}, \tau_{i}, e_{i}$ are determined independently from $T_{j}, \tau_{j}, e_{j}$ for any two municipalities $i$ and $j$. Moreover, the first-order condition for $e_{i}$ is independent of the remaining first-order conditions. So, the conditions determining $T_{i}, \tau_{i}$ can be written

$$
\begin{aligned}
(\lambda+B) f^{\prime}\left(\tau_{i}+T_{i}\right) & =\Psi^{\prime}\left(T_{i}\right) \\
f^{\prime}\left(\tau_{i}+T_{i}\right) & =d^{\prime}\left(\tau_{i}\right)
\end{aligned}
$$

where

$$
B=x \zeta_{i}-(1-x) \zeta_{i}
$$

and where $x=1$ if $i \in M_{A}, \quad x=0$ if $i \in M_{N}$. Totally differentiating (A3)-(A4), by Cramer's rule, we get:

$$
\frac{d T_{i}}{d B}=\frac{\left|\begin{array}{cc}
-f^{\prime} & (\lambda+B) f^{\prime \prime} \\
0 & f^{\prime \prime}-d^{\prime \prime}
\end{array}\right|}{\left|\begin{array}{cc}
(\lambda+B) f^{\prime \prime} & (\lambda+B) f^{\prime \prime} \\
f^{\prime \prime} & f^{\prime \prime}-d^{\prime \prime}
\end{array}\right|}=\frac{-f^{\prime}\left(f^{\prime \prime}-d^{\prime \prime}\right)}{D}
$$

where $D=d^{\prime \prime}-f^{\prime \prime}(\lambda+B) d^{\prime \prime}>0$ from $f^{\prime \prime}<0, d^{\prime \prime}>0$. So, consequently, from (A5), $\frac{d T}{d B}>0$. So, as 
$B=\zeta_{i}$ if $i$ is aligned, and $B=-\zeta_{j}$ if $j$ is non-aligned, then $T_{i}>T_{j}$.

Proof of Proposition 5. Expected voter utility in $i$ is

$$
E \ln g_{i}-d\left(\tau_{i}\right)=f\left(\tau_{i}+T_{i}\right)+e_{i}-d\left(\tau_{i}\right)
$$

We need to show that for any two $i, j$ where $i$ is aligned and $j$ is not, that expected voter utility is higher in $i$. Note first that from Proposition 2, 3, and 4, $\tau_{i}$ is lower when aligned i.e. $\tau_{i}<\tau_{j}$. So, we need $f\left(\tau_{i}+T_{i}\right)+e_{i}$ to be higher than $f\left(\tau_{i}+T_{i}\right)+e_{i}$. As $e_{i}$ is increasing in $\zeta_{i}, \zeta_{i} \geq \zeta_{j}$ ensures $e_{i} \geq e_{j}$. Then note that from Proposition 2, 3, and 4, $T_{i}>T_{j}$, and thus, as $\tau_{i}$ falls less than one for one with an increase in $T_{i}, \tau_{i}+T_{i}$ will be higher also. 
Table AA1. Political alignment and grant allocation

\begin{tabular}{|c|c|c|c|c|}
\hline Regression specifications & $\begin{array}{c}\text { No } \\
\text { Controls }\end{array}$ & $\begin{array}{l}\text { With } \\
\text { Controls }\end{array}$ & $\begin{array}{l}\text { With controls \& } \\
\text { Fixed Effect }\end{array}$ & Observations \\
\hline \multirow[t]{2}{*}{$\begin{array}{l}\text { OLS regression (all } \\
\text { sample) }\end{array}$} & $0.555^{* * *}$ & $0.138^{* * *}$ & $0.134^{* * *}$ & \multirow[t]{2}{*}{3546} \\
\hline & $(0.0324)$ & $(0.0218)$ & $(0.0314)$ & \\
\hline \multirow{2}{*}{$\begin{array}{l}\text { OLS regression (all } \\
\text { sample, } 2 \text { nd round) }\end{array}$} & $0.386^{* * *}$ & $0.143^{* * *}$ & $0.131^{* * *}$ & \multirow[t]{2}{*}{1431} \\
\hline & $(0.0523)$ & $(0.0343)$ & $(0.0444)$ & \\
\hline \multirow[t]{2}{*}{$\begin{array}{l}\text { First order polynomial } \\
\text { (RD Sample) }\end{array}$} & $0.263^{* * *}$ & $0.257^{* * *}$ & $0.265^{* * *}$ & \multirow[t]{2}{*}{3141} \\
\hline & $(0.0663)$ & $(0.044)$ & $(0.0572)$ & \\
\hline \multirow[t]{2}{*}{$\begin{array}{l}\text { Second order polynomial } \\
\text { (RD Sample) }\end{array}$} & $0.462^{* * *}$ & $0.323^{* * *}$ & $0.289^{* * *}$ & \multirow[t]{2}{*}{3141} \\
\hline & $(0.099)$ & $(0.0652)$ & $(0.0816)$ & \\
\hline \multirow[t]{2}{*}{$\begin{array}{l}\text { Third order polynomial } \\
\text { (RD Sample) }\end{array}$} & $0.571^{* * *}$ & $0.414 * * *$ & $0.432^{* * *}$ & \multirow[t]{2}{*}{3141} \\
\hline & $(0.128)$ & $(0.085)$ & $(0.108)$ & \\
\hline \multirow[t]{2}{*}{$\begin{array}{l}\text { Fourth order polynomial } \\
\text { (RD Sample) }\end{array}$} & $\underline{0.475^{* * *}}$ & $\underline{0.364 * * *}$ & $\underline{0.365^{* * *}}$ & \multirow[t]{2}{*}{3141} \\
\hline & $(0.157)$ & -0.105 & $(0.137)$ & \\
\hline \multirow[t]{2}{*}{$\begin{array}{l}\text { First order polynomial } \\
\text { (RD Sample, 2nd round ) }\end{array}$} & $0.280 * *$ & $0.333^{* * *}$ & $0.335^{* * *}$ & \multirow[t]{2}{*}{1263} \\
\hline & $(0.112)$ & $(0.0718)$ & $(0.0852)$ & \\
\hline \multirow[t]{2}{*}{$\begin{array}{l}\text { Second order polynomial } \\
\text { (RD Sample, 2nd round) }\end{array}$} & 0.124 & $0.289 * * *$ & $0.254^{* *}$ & \multirow[t]{2}{*}{1263} \\
\hline & $(0.148)$ & $(0.0957)$ & $(0.117)$ & \\
\hline \multirow[t]{2}{*}{$\begin{array}{l}\text { Third order polynomial } \\
\text { (RD Sample, 2nd round) }\end{array}$} & $0.423^{* *}$ & $0.499 * * *$ & $0.405^{* * *}$ & \multirow[t]{2}{*}{1263} \\
\hline & $(0.185)$ & $(0.119)$ & $(0.151)$ & \\
\hline \multirow[t]{2}{*}{$\begin{array}{l}\text { Fourth order polynomial } \\
\text { (RD Sample, 2nd round) }\end{array}$} & $0.713^{* * *}$ & $0.588^{* * *}$ & $0.523^{* * *}$ & \multirow[t]{2}{*}{1263} \\
\hline & $(0.219)$ & $(0.147)$ & $(0.195)$ & \\
\hline \multirow[t]{2}{*}{$\begin{array}{l}\text { Local Linear regression } \\
\text { (h) }\end{array}$} & $0.326^{* * *}$ & $0.403^{* * *}$ & $0.439 * * *$ & \multirow[t]{2}{*}{856} \\
\hline & $(0.120)$ & $(0.121)$ & $(0.0930)$ & \\
\hline \multirow[t]{2}{*}{$\begin{array}{l}\text { Local linear regression } \\
\text { (half } \mathrm{h})\end{array}$} & 0.174 & $0.449^{* *}$ & $0.301^{* *}$ & \multirow[t]{2}{*}{324} \\
\hline & $(0.183)$ & $(0.182)$ & $(0.137)$ & \\
\hline \multirow[t]{2}{*}{$\begin{array}{l}\text { Local linear regression } \\
\text { (double h) }\end{array}$} & $0.319^{* * *}$ & $0.348^{* * *}$ & $0.303^{* * *}$ & \multirow[t]{2}{*}{1750} \\
\hline & $(0.0792)$ & $(0.0838)$ & $(0.0643)$ & \\
\hline
\end{tabular}

Notes. The table reports coefficients on alignment dummies. RD sample included all municipal elections where the winner and the runner up belong to the centre-left and centre-right coalition. Controls include: municipal population and population squared, income per capita, income per capita from real estate, proportion of population under 14 and over 65 years old. Time dummies are included in all regressions in columns 2 and 3. Optimally chosen bandwidth (h) in local linear regressions is $+/-13$. Significance at $1 \%$ is represented by *** , at $5 \%$ by ** and at $10 \%$ by *. Robust standard errors in brackets clustered at municipal level. 
Table AA2. Alignment and the probability of incumbent re-election

\begin{tabular}{|c|c|c|c|c|c|c|c|c|}
\hline \multirow[b]{2}{*}{$\begin{array}{l}\text { Coefficient on } \\
\text { Alignment }\end{array}$} & \multicolumn{3}{|c|}{ Panel 1: Incumbent Party } & \multirow[b]{2}{*}{ Obs. } & \multicolumn{3}{|c|}{ Panel 2: Incumbent Candidate } & \multirow[b]{2}{*}{ Obs. } \\
\hline & $\begin{array}{l}\text { No } \\
\text { controls }\end{array}$ & Controls & $\begin{array}{l}\text { Controls } \\
\quad \& \mathrm{FE}\end{array}$ & & $\begin{array}{l}\text { No } \\
\text { controls }\end{array}$ & Controls & $\begin{array}{l}\text { Controls } \\
\& \mathrm{FE}\end{array}$ & \\
\hline Linear regression & $\begin{array}{c}0.0279 \\
(0.0275)\end{array}$ & $\begin{array}{l}0.144^{* * *} \\
(0.0378)\end{array}$ & $\begin{array}{l}0.156^{* * *} \\
(0.0359)\end{array}$ & 768 & $\begin{array}{l}0.156^{* * *} \\
(0.0373)\end{array}$ & $\begin{array}{l}0.119 * * * \\
(0.0433)\end{array}$ & $\begin{array}{l}0.128^{* * *} \\
(0.042)\end{array}$ & 641 \\
\hline \multirow[t]{2}{*}{ First order polynomial } & 0.135 & $0.240^{* * *}$ & $0.189^{* * *}$ & 363 & $0.303^{* * *}$ & $0.265^{* * *}$ & $0.191^{*}$ & 205 \\
\hline & $(0.0845)$ & $(0.0641)$ & $(0.0648)$ & & $(0.0960)$ & $(0.0933)$ & $(0.101)$ & \\
\hline \multirow{2}{*}{$\begin{array}{c}\text { Second order } \\
\text { polynomial (RD Sample) }\end{array}$} & $\underline{0.208}$ & $\underline{0.312^{* * *}}$ & $\underline{0.267^{* * *}}$ & 363 & $\underline{0.358^{* *}}$ & $\underline{0.314^{* *}}$ & $\underline{0.256^{*}}$ & 205 \\
\hline & $(0.130)$ & $(0.101)$ & $(0.101)$ & & $(0.140)$ & $(0.134)$ & $(0.141)$ & \\
\hline $\begin{array}{l}\text { Third order polynomial } \\
\text { (RD Sample) }\end{array}$ & $0.403^{* *}$ & $0.403^{* * *}$ & $0.335^{* *}$ & 363 & $0.581^{* * *}$ & $0.513^{* * *}$ & $0.411^{* *}$ & 205 \\
\hline \multirow{3}{*}{$\begin{array}{l}\text { Fourth order polynomial } \\
\text { (RD Sample) }\end{array}$} & $(0.165)$ & $(0.134)$ & $(0.136)$ & & $(0.179)$ & $(0.172)$ & $(0.186)$ & \\
\hline & 0.337 & $0.334^{*}$ & 0.287 & 363 & $0.555^{* * *}$ & $0.423^{*}$ & 0.352 & 205 \\
\hline & $(0.209)$ & $(0.177)$ & $(0.184)$ & & $(0.210)$ & $(0.215)$ & $(0.222)$ & \\
\hline \multirow[t]{2}{*}{$\begin{array}{l}\text { Local Linear regression } \\
\text { (h) }\end{array}$} & $0.759 * *$ & 0.521 & & 26 & $0.623^{*}$ & 0.119 & & 22 \\
\hline & $(0.356)$ & $(0.468)$ & & & $(0.357)$ & $(0.428)$ & & \\
\hline \multirow{2}{*}{$\begin{array}{l}\text { Local linear regression } \\
\text { (half } \mathrm{h} \text { ) }\end{array}$} & $0.840^{* *}$ & 0.838 & & 17 & 0.714 & 0.778 & & 15 \\
\hline & $(0.387)$ & $(0.828)$ & & & $(0.470)$ & $(0.631)$ & & \\
\hline \multirow{2}{*}{$\begin{array}{l}\text { Local linear regression } \\
\text { (double h) }\end{array}$} & $0.631^{* *}$ & $0.715^{* *}$ & & 42 & $0.611^{*}$ & 0.303 & & 33 \\
\hline & $(0.290)$ & $(0.356)$ & & & $(0.300)$ & $(0.282)$ & & \\
\hline
\end{tabular}

Notes. The table reports coefficients on alignment dummies. RD sample included all municipal elections where the winner and the runner up belong to the centre-left and centre-right coalition. Controls include: municipal population and population squared, income per capita, income per capita from real estate, proportion of population under 14 and over 65 years old. Time dummies are included in all regressions in columns 2 and 3, 5 and 6. Optimally chosen bandwidth (h) in local linear regressions is $+/-3.5 \%$. Significance at $1 \%$ is represented by ${ }^{* * *}$, at $5 \%$ by ${ }^{* *}$ and at $10 \%$ by ${ }^{*}$. Robust standard errors in brackets clustered at municipal level. 
Table AA3. Descriptive statistics, means and differences in means between aligned and non-aligned (regression sample)

\begin{tabular}{|c|c|c|c|c|}
\hline & Aligned & $\begin{array}{l}\text { Not } \\
\text { Aligned }\end{array}$ & Diff. & $\begin{array}{c}\text { P-value } \\
\text { HO: diff } \neq 0\end{array}$ \\
\hline $\begin{array}{l}\text { Current grants from central government, real euro } \\
\text { per-capita }\end{array}$ & 177.42 & 132.50 & 44.92 & 0.0000 \\
\hline $\begin{array}{l}\text { Current grants from regional government, real } \\
\text { euro per-capita }\end{array}$ & 44.33 & 46.86 & -2.53 & 0.1125 \\
\hline $\begin{array}{l}\text { Total municipal taxes (property }+ \text { income tax), real } \\
\text { euro per capita }\end{array}$ & 236.88 & 250.85 & -13.97 & 0.0000 \\
\hline Current municipal fees real euro per-capita & 274.06 & 262.76 & 11.3 & 0.3266 \\
\hline $\begin{array}{l}\text { Current municipal expenditure } \\
\text { real euro per-capita }\end{array}$ & 792. 8 & 788.88 & 3.400 & 0.3336 \\
\hline $1=$ if incumbent mayor is re-elected & 0.7827 & 0.7945 & -0.011 & 0.7184 \\
\hline $1=$ if incumbent party is re-elected & 0.7961 & 0.8098 & -0.013 & 0.9095 \\
\hline $1=$ if mayor elected at the second round & 0.4403 & 0.4409 & -0.000 & 0.9647 \\
\hline Margin of victory, municipal elections & 21.71 & 21.94 & -0.230 & 0.9746 \\
\hline $\begin{array}{l}1=\text { if municipality is aligned with the regional } \\
\text { government }\end{array}$ & 0.6111 & 0.5880 & 0.0231 & 0.0809 \\
\hline Resident population & 53,804 & 56,862 & $-3,058$ & 0.4200 \\
\hline Percentage of residents under 15 years old & 14.63 & 14.50 & 0.130 & 0.0114 \\
\hline Percentage of residents over 65 years old & 17.42 & 17.68 & -0.260 & 0.0038 \\
\hline $\begin{array}{l}\text { Income different form real estate, real euro per- } \\
\text { capita }\end{array}$ & 16,786 & 16,919 & -133 & 0.2338 \\
\hline Income from real estate, real euro per-capita & 1,779 & 1,775 & 4.000 & 0.8669 \\
\hline $\begin{array}{l}\text { Municipal electoral cycle }(0=\text { election year, } \\
4=\text { year before election })\end{array}$ & 1.80 & 1.87 & -0.070 & 0.1343 \\
\hline $\begin{array}{l}\text { Local government dummy } \\
(1=\text { left council) }\end{array}$ & 0.4928 & 0.7314 & -0.238 & 0.0000 \\
\hline $\begin{array}{l}\text { Central government dummy } \\
(1=\text { left central government })\end{array}$ & 0.3578 & 0.2673 & 0.090 & 0.0002 \\
\hline
\end{tabular}


Table AA4. Political classification of parties (1998-2008)

\begin{tabular}{|c|c|c|c|c|c|}
\hline Center-Left & No. & Center-Right & No. & Independents & No. \\
\hline CEN-SIN(LS.CIVICHE) & 2,565 & CEN-DES(LS.CIVICHE) & 1,245 & LISTA CIVICA & 265 \\
\hline CEN-SIN & 629 & CEN-DES & 403 & IND & 57 \\
\hline DEMOCRATICI SINISTRA & 246 & FORZA ITALIA & 251 & SVP & 20 \\
\hline PDS & 193 & LEGA NORD & 181 & UV & 7 \\
\hline SINISTRA & 140 & CENTRO & 127 & PATTO SEGNI & 6 \\
\hline L'ULIVO & 84 & ALLEANZA NAZIONALE & 87 & DEMOCRAZIA EUROPEA & 5 \\
\hline P.POPOLARE ITALIANO & 39 & POLO PER LE LIBERTA' & 30 & MOV. PER L'AUTONOMIA & 5 \\
\hline PPI (POP) & 27 & $\mathrm{CCD}$ & 26 & RINNOV.IT-ALTRI & 5 \\
\hline DL.LA MARGHERITA & 18 & CASA DELLE LIBERTA' & 17 & SI & 4 \\
\hline RIF.COM. & 17 & $\mathrm{CDU}$ & 14 & LISTA LOCALE & 1 \\
\hline LA MARGHERITA & 16 & IL POPOLO DELLA LIBE & 13 & PRI & 1 \\
\hline PROGRESSISTI (1994) & 8 & LEGA LOMB-LEGA NORD & 10 & & \\
\hline CEN-SIN(CONTR.UFF.) & 7 & LG.NORD-LG.VENETA & 10 & & \\
\hline PARTITO DEMOCRATICO & 7 & L.VEN-L.NORD & 9 & & \\
\hline POPOLARI & 6 & LISTA CIVICA & 9 & & \\
\hline IND.SIN. & 5 & UDC & 9 & & \\
\hline PER VERONA & 5 & $\mathrm{CCD}-\mathrm{CDU}$ & 7 & & \\
\hline PROGRESSISTI SALERNO & 5 & DESTRA & 7 & & \\
\hline SDI-ALTRI & 5 & FI-CCD & 5 & & \\
\hline FED.DEI VERDI & 4 & FI-CCD-AN & 5 & & \\
\hline UNITI NELL'ULIVO & 4 & POLO BUON GOVERNO & 5 & & \\
\hline ALL. DI PROGRESSO & 3 & $\mathrm{CDL}$ & 4 & & \\
\hline CENSIN & 3 & CENDES & 4 & & \\
\hline I DEMOCRATICI & 3 & LG.VENETA REPUBBLICA & 4 & & \\
\hline LA MARG. & 2 & U.D.EUR & 3 & & \\
\hline SDI & 2 & U.D.EUR POPOLARI & 1 & & \\
\hline SOCIALISTIALTRI & 2 & FI-CCD-CDU & 1 & & \\
\hline U.D.EUR & 2 & FORZA IT.-POLO POP. & 1 & & \\
\hline U.D.EUR POPOLARI & 2 & PDL & 1 & & \\
\hline P.DEM. & 1 & & & & \\
\hline PATTO DEMOCRATICI & 1 & & & & \\
\hline POPOLARI-CIVICA & 1 & & & & \\
\hline VERDI & 1 & & & & \\
\hline TOTAL & 4,053 & & 2,489 & & 376 \\
\hline
\end{tabular}

Notes: Frequencies record the number of elected mayors in large municipalities classified as supported by each party. U.D.EUR and U.D.EUR POPOLARI are classified as a Center-Left party for the years 2006-2008 when they supported the center-left government. 
Table AA5. Large municipalities

\begin{tabular}{c|c|c|c}
\hline \hline years & $\begin{array}{c}\text { Large } \\
\text { municipalities } \\
\text { as \% of total } \\
\text { municipalities }\end{array}$ & $\begin{array}{c}\text { \% of residents in } \\
\text { large } \\
\text { municipalities }\end{array}$ & $\begin{array}{c}\% \text { of total grants to } \\
\text { large municipalities }\end{array}$ \\
\hline 2002 & $9.41 \%$ & $60.87 \%$ & $65.97 \%$ \\
2003 & $9.41 \%$ & $60.86 \%$ & $64.93 \%$ \\
2004 & $9.41 \%$ & $60.99 \%$ & $65.55 \%$ \\
2005 & $9.41 \%$ & $60.80 \%$ & $66.23 \%$ \\
2006 & $9.41 \%$ & $60.84 \%$ & $65.98 \%$ \\
2007 & $9.41 \%$ & $60.65 \%$ & $68.86 \%$ \\
2008 & $9.41 \%$ & $60.55 \%$ & $70.64 \%$ \\
2009 & $9.41 \%$ & $60.50 \%$ & $70.49 \%$ \\
2010 & $9.41 \%$ & $60.54 \%$ & $69.33 \%$ \\
2011 & $9.41 \%$ & $60.23 \%$ & $68.90 \%$ \\
\hline \hline
\end{tabular}

Table AA6. Distribution of elections by first round and second round (regression sample)

\begin{tabular}{|c|c|c|c|c|c|c|c|}
\hline \multirow[b]{2}{*}{ year } & \multicolumn{3}{|c|}{ First round } & \multicolumn{3}{|c|}{ Second round } & \multirow{2}{*}{$\begin{array}{l}\text { Total } \\
\text { election }\end{array}$} \\
\hline & $\begin{array}{c}\text { Center-right } \\
\text { wins }\end{array}$ & $\begin{array}{c}\text { Center-left } \\
\text { wins }\end{array}$ & Total & $\begin{array}{l}\text { Center-right } \\
\text { wins }\end{array}$ & $\begin{array}{c}\text { Center-left } \\
\text { wins }\end{array}$ & Total & \\
\hline 1998 & 4 & 12 & 16 & 17 & 11 & 28 & 44 \\
\hline 1999 & 13 & 84 & 97 & 34 & 38 & 72 & 169 \\
\hline 2000 & 7 & 10 & 17 & 12 & 16 & 28 & 45 \\
\hline 2001 & 22 & 17 & 39 & 25 & 25 & 50 & 89 \\
\hline 2002 & 40 & 34 & 74 & 19 & 34 & 53 & 127 \\
\hline 2003 & 11 & 15 & 26 & 6 & 14 & 20 & 46 \\
\hline 2004 & 16 & 105 & 121 & 27 & 39 & 66 & 187 \\
\hline 2005 & 15 & 24 & 39 & 3 & 21 & 24 & 63 \\
\hline 2006 & 27 & 39 & 66 & 17 & 23 & 40 & 106 \\
\hline 2007 & 40 & 23 & 63 & 35 & 19 & 54 & 117 \\
\hline 2008 & 14 & 7 & 21 & 20 & 16 & 36 & 57 \\
\hline Total & 209 & 370 & 579 & 215 & 256 & 471 & 1050 \\
\hline
\end{tabular}


Table AA7. Local elections by coalition and margin of victory (regression sample)

\begin{tabular}{|c|c|c|c|c|c|c|}
\hline \multirow[b]{2}{*}{ year } & \multicolumn{2}{|c|}{ All sample } & \multicolumn{2}{|c|}{ MV < 5\% } & \multicolumn{2}{|c|}{$\mathrm{MV}<2 \%$} \\
\hline & $\begin{array}{c}\text { Center-right } \\
\text { wins }\end{array}$ & $\begin{array}{c}\text { Center-left } \\
\text { wins }\end{array}$ & $\begin{array}{c}\text { Center-right } \\
\text { wins }\end{array}$ & $\begin{array}{l}\text { Center-left } \\
\text { wins }\end{array}$ & $\begin{array}{c}\text { Center-right } \\
\text { wins }\end{array}$ & $\begin{array}{c}\text { Center-left } \\
\text { wins }\end{array}$ \\
\hline 1998 & 21 & 23 & 3 & 1 & 0 & 0 \\
\hline 1999 & 47 & 122 & 12 & 10 & 4 & 3 \\
\hline 2000 & 19 & 26 & 2 & 4 & 2 & 1 \\
\hline 2001 & 47 & 42 & 4 & 6 & 1 & 1 \\
\hline 2002 & 59 & 68 & 7 & 8 & 5 & 4 \\
\hline 2003 & 17 & 29 & 1 & 1 & 0 & 1 \\
\hline 2004 & 43 & 144 & 12 & 8 & 7 & 5 \\
\hline 2005 & 18 & 45 & 3 & 5 & 1 & 3 \\
\hline 2006 & 44 & 62 & 8 & 5 & 1 & 2 \\
\hline 2007 & 75 & 42 & 6 & 4 & 3 & 1 \\
\hline 2008 & 34 & 23 & 4 & 3 & 4 & 2 \\
\hline Total & 424 & 626 & 62 & 55 & 28 & 23 \\
\hline
\end{tabular}

Table AA8. Local elections by coalition and alignment status (regression sample)

\begin{tabular}{c|cc|cc|cc}
\hline \hline \multirow{2}{*}{ year } & \multicolumn{2}{|c|}{ All sample } & \multicolumn{2}{c|}{ MV $<$ 5\% } & \multicolumn{2}{c}{ MV < 2\% } \\
& Aligned & Not-Aligned & Aligned & Not-Aligned & Aligned & Not-Aligned \\
\hline 1998 & 21 & 23 & 3 & 1 & 0 & 0 \\
1999 & 47 & 122 & 12 & 10 & 4 & 3 \\
2000 & 19 & 26 & 2 & 4 & 2 & 1 \\
2001 & 42 & 47 & 6 & 4 & 1 & 1 \\
2002 & 68 & 59 & 8 & 7 & 4 & 5 \\
2003 & 29 & 17 & 1 & 1 & 1 & 0 \\
2004 & 144 & 43 & 8 & 12 & 5 & 7 \\
2005 & 45 & 18 & 5 & 3 & 3 & 1 \\
2006 & 44 & 62 & 8 & 5 & 1 & 2 \\
2007 & 75 & 42 & 6 & 4 & 3 & 1 \\
2008 & 23 & 34 & 3 & 4 & 2 & 4 \\
\hline Total & 557 & 493 & 62 & 55 & 26 & 25 \\
\hline \hline
\end{tabular}


Table AA9. Descriptive statistics, means and standard deviations by margin of alignment, second round elections, (regression sample)

\begin{tabular}{|c|c|c|c|c|c|c|}
\hline & \multicolumn{3}{|c|}{ Mean } & \multicolumn{3}{|c|}{ Std. Dev. } \\
\hline & $\begin{array}{c}\text { All } \\
\text { sample }\end{array}$ & $\begin{array}{c}M V \\
<5 \% \\
\end{array}$ & $\begin{array}{c}M V \\
<2 \% \\
\end{array}$ & $\begin{array}{c}\text { All } \\
\text { sample }\end{array}$ & $\begin{array}{r}M V \\
<5 \% \\
\end{array}$ & $\begin{array}{l}M V \\
<2 \% \\
\end{array}$ \\
\hline $\begin{array}{l}\text { Current grants from central } \\
\text { government, real euro per-capita }\end{array}$ & 155.88 & 161.84 & 151.94 & 92.12 & 90.90 & 91.13 \\
\hline $\begin{array}{l}\text { Current grants from regional } \\
\text { government, real euro per-capita }\end{array}$ & 46.66 & 48.52 & 48.76 & 46.07 & 46.82 & 54.35 \\
\hline $\begin{array}{l}\text { Total municipal taxes (property }+ \\
\text { income tax) - real euro per capita }\end{array}$ & 229.54 & 232.40 & 251.87 & 80.05 & 79.15 & 69.92 \\
\hline $\begin{array}{l}\text { Current municipal fees real euro per- } \\
\text { capita }\end{array}$ & 258.33 & 258.69 & 279.58 & 133.63 & 134.87 & 149.21 \\
\hline $\begin{array}{l}\text { Current municipal expenditure } \\
\text { real euro per-capita }\end{array}$ & 755.15 & 767.51 & 808.89 & 190.85 & 201.26 & 185.98 \\
\hline $1=$ if incumbent mayor is re-elected & 0.6703 & 0.6250 & 0.4545 & 0.4710 & 0.4880 & 0.5096 \\
\hline $1=$ if incumbent party is re-elected & 0.6778 & 0.6456 & 0.4839 & 0.4680 & 0.4814 & 0.5080 \\
\hline Margin of victory, municipal election & 12.4520 & 3.8259 & 3.3667 & 9.6211 & 5.0825 & 7.0532 \\
\hline $\begin{array}{l}1=\text { if municipality is aligned with the } \\
\text { central government }\end{array}$ & 0.4855 & 0.5010 & 0.5450 & 0.4999 & 0.5005 & 0.4992 \\
\hline $\begin{array}{l}1=\text { if municipality is aligned with the } \\
\text { regional government }\end{array}$ & 0.4854 & 0.5010 & 0.5400 & 0.4999 & 0.5005 & 0.4992 \\
\hline Resident population & 52,574 & 67,797 & 49,734 & 174,964 & 257,521 & 71,367 \\
\hline $\begin{array}{l}\text { Percentage of residents under } 15 \text { years } \\
\text { old }\end{array}$ & 15.04 & 14.83 & 13.91 & 3.13 & 3.30 & 2.49 \\
\hline $\begin{array}{l}\text { Percentage of residents over } 65 \text { years } \\
\text { old }\end{array}$ & 16.79 & 17.03 & 18.04 & 4.32 & 4.22 & 3.93 \\
\hline $\begin{array}{l}\text { Income different form real estate real } \\
\text { euro per-capita }\end{array}$ & 16,713 & 16,994 & 18,056 & 3,323 & 3,168 & 2,770 \\
\hline $\begin{array}{l}\text { Income from real estate, real euro per- } \\
\text { capita }\end{array}$ & 1,743 & 1,756 & 1,852 & 514 & 511 & 556 \\
\hline $\begin{array}{l}\text { Electoral cycle }(0=\text { election year, } \\
4 \text { = year before election) }\end{array}$ & 1.804 & 1.844 & 1.775 & 1.361 & 1.376 & 1.365 \\
\hline $\begin{array}{l}\text { Local government dummy } \\
(1=\text { left council) }\end{array}$ & 0.5513 & 0.4723 & 0.4350 & 0.4975 & 0.4997 & 0.4970 \\
\hline $\begin{array}{l}\text { Central government dummy } \\
(1=\text { left central government) }\end{array}$ & 0.3019 & 0.3018 & 0.2800 & 0.4592 & 0.4595 & 0.4501 \\
\hline
\end{tabular}

Number of observations: All sample $=2,097 \mathrm{MV}<5 \%=487 \mathrm{MV}<5 \%=200$ 
Table AA10. Testing for flypaper effect, determination of current expenditures net of grants from central government and regional governments (Euros per capita)

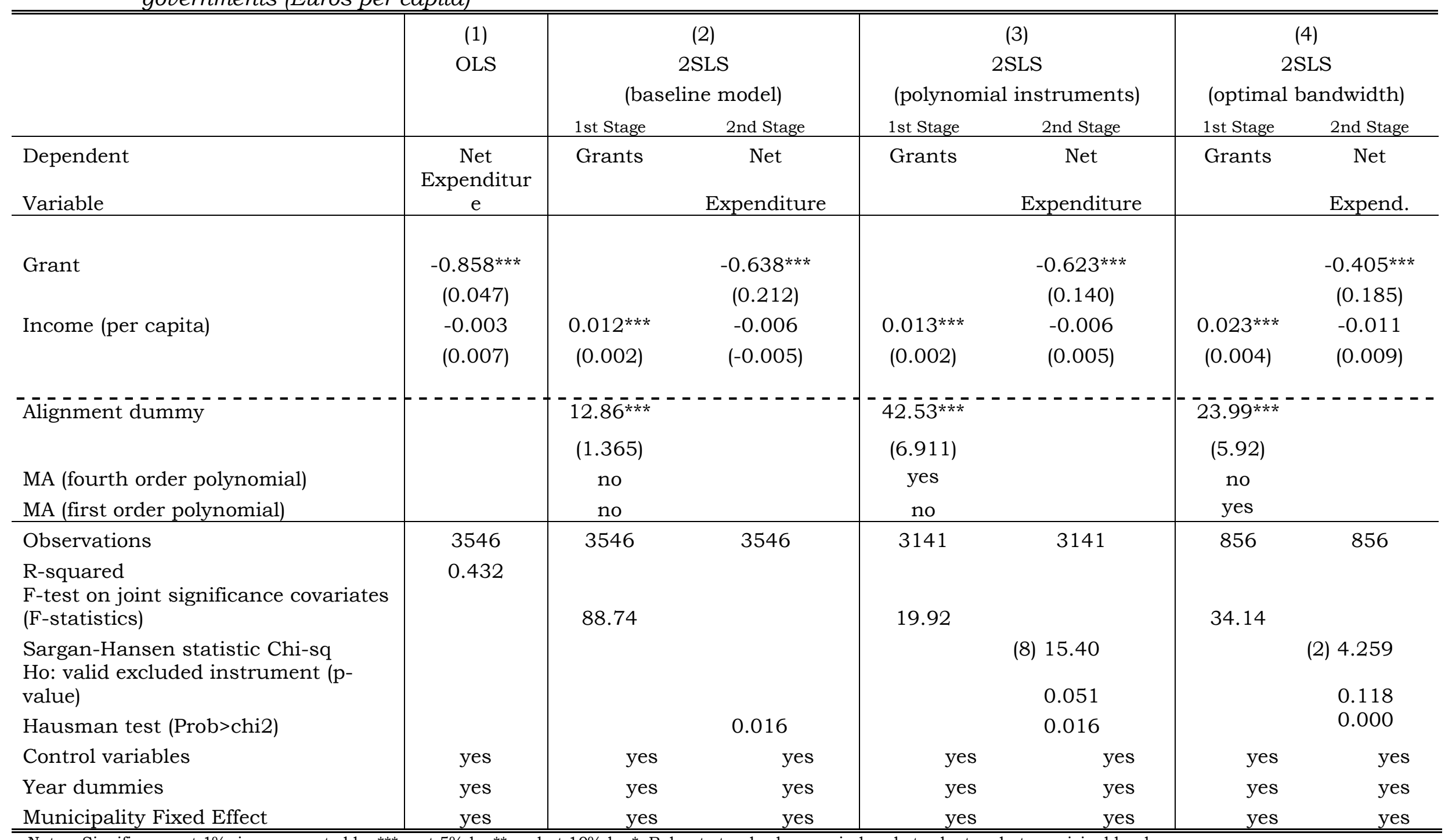

Municipality Fixed Effect

Controls include: Resident population, Percentage of residents under15 years old, Percentage of residents over 65 years old, Electoral cycle, Local government dummy $(1=$ left council $)$, Central government dummy $(1=$ left central government $)$, Municipal alignment with the regional government dummy $(1=$ aligned municipality), Current grants from regional government (real euro per-capita). 
Table AA11. Testing for flypaper effect, determination of current expenditures (Euros per capita)

\begin{tabular}{|c|c|c|c|c|c|c|c|}
\hline & \multirow[t]{2}{*}{$\begin{array}{l}\text { (1) } \\
\text { OLS }\end{array}$} & \multicolumn{2}{|c|}{$\begin{array}{c}(2) \\
\text { 2SLS } \\
\text { (baseline model) }\end{array}$} & \multicolumn{2}{|c|}{$\begin{array}{c}(3) \\
2 \mathrm{SLS} \\
\text { (polynomial instrument) }\end{array}$} & \multicolumn{2}{|c|}{$\begin{array}{c}(4) \\
2 \mathrm{SLS} \\
\text { (optimal bandwidth) }\end{array}$} \\
\hline & & 1st Stage & 2nd Stage & 1st Stage & 2nd Stage & 1st Stage & 2nd Stage \\
\hline $\begin{array}{l}\text { Dependent } \\
\text { Variable }\end{array}$ & $\begin{array}{c}\text { Current } \\
\text { Expenditures }\end{array}$ & Grants & $\begin{array}{c}\text { Current } \\
\text { Expenditures }\end{array}$ & Grants & $\begin{array}{c}\text { Current } \\
\text { Expenditures }\end{array}$ & Grants & $\begin{array}{c}\text { Current } \\
\text { Expenditures }\end{array}$ \\
\hline Grant & $\begin{array}{l}0.142^{* * *} \\
(0.0478)\end{array}$ & & $\begin{array}{l}0.362^{*} \\
(0.211)\end{array}$ & & $\begin{array}{c}0.377^{* * *} \\
(0.140)\end{array}$ & & $\begin{array}{c}0.595^{* * *} \\
(0.185)\end{array}$ \\
\hline Income (per capita) & $\begin{array}{l}-0.00374 \\
(0.00770)\end{array}$ & $\begin{array}{c}0.011^{* * *} \\
(0.002)\end{array}$ & $\begin{array}{l}-0.00631 \\
(0.00497)\end{array}$ & $\begin{array}{c}0.013^{* * *} \\
(0.002)\end{array}$ & $\begin{array}{l}-0.006 \\
(0.005)\end{array}$ & $\begin{array}{c}0.023^{* * *} \\
(0.004)\end{array}$ & $\begin{array}{l}-0.011 \\
(0.048)\end{array}$ \\
\hline $\begin{array}{l}\text { Alignment dummy } \\
\text { MA (fourth order polynomial) } \\
\text { MA (first order polynomial) }\end{array}$ & & 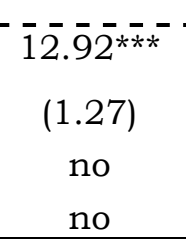 & & $\begin{array}{c}42.53^{* * *} \\
(6.91) \\
\text { yes } \\
\text { no }\end{array}$ & & $\begin{array}{c}\overline{2} \overline{3} . \overline{9} \overline{9}^{* * *} \\
(5.92) \\
\text { no } \\
\text { yes }\end{array}$ & \\
\hline $\begin{array}{l}\text { Observations } \\
\text { R-squared } \\
\text { F-test on joint significance covariates } \\
\text { (F-statistics) }\end{array}$ & $\begin{array}{l}3546 \\
0.149\end{array}$ & 88.74 & 3546 & $\begin{array}{l}3141 \\
19.92\end{array}$ & 3141 & 34.14 & 856 \\
\hline $\begin{array}{l}\text { Sargan-Hansen statistic Chi-sq } \\
\text { Ho: valid excluded instrument (p- } \\
\text { value) } \\
\text { Hausman test (Prob>chi2) }\end{array}$ & & & 0.034 & & (8) $\begin{array}{r}15.40 \\
0.051 \\
0.034\end{array}$ & & $\begin{array}{l}\text { (2) } 4.29 \\
0.118 \\
0.000\end{array}$ \\
\hline Control variables & yes & yes & yes & yes & yes & yes & yes \\
\hline Year dummies & yes & yes & yes & yes & yes & yes & yes \\
\hline Municipality Fixed Effect & yes & yes & yes & yes & yes & yes & yes \\
\hline
\end{tabular}

